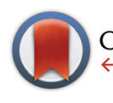

CrossMark $\leftarrow$ click for updates

Cite this: Dalton Trans., 2015, 44 19615

Received 25th May 2015,

Accepted 20th July 2015

DOI: $10.1039 / c 5 d t 01959 a$

www.rsc.org/dalton

\section{Phase and redox shifted four iron/four sulfur clusters: fluorous analogs of metalloenzyme cofactors $\uparrow$}

\author{
Cheng-Pan Zhang, $t^{\mathrm{a}}$ Zhenxing Xi, ${ }^{a}$ Kory M. Mueller, ${ }^{\mathrm{b}}$ Bradley J. Holliday, ${ }^{\mathrm{b}}$ \\ Hassan S. Bazzi*C and John A. Gladysz ${ }^{* a}$
}

Reactions of (1) $[\mathrm{Q}]_{2}\left[\mathrm{Fe}_{4} \mathrm{~S}_{4}\left(\mathrm{SC}\left(\mathrm{CH}_{3}\right)_{3}\right)_{4}\right]$ and the fluorous thiols $\left.\mathrm{HS}\left(\mathrm{CH}_{2}\right)_{n} \mathrm{R}_{\mathrm{f8}}\left(n=2,3 ; \mathrm{R}_{\mathrm{f8}}=\left(\mathrm{CF}_{2}\right)_{7} \mathrm{CF}_{3}\right)\right)$, or

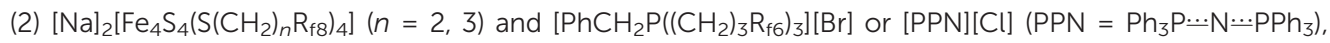
give the title compounds $[\mathrm{Q}]_{2}\left[\mathrm{Fe}_{4} \mathrm{~S}_{4}\left(\mathrm{~S}_{(}\left(\mathrm{CH}_{2}\right)_{n} \mathrm{R}_{\mathrm{f}}\right)_{4}\right]$, comprised of a fluorous dianion and in some cases fluorous cations, with (1) $\mathrm{Q} / n=\mathrm{Ph}_{4} \mathrm{P} / 2$ (4, 67\%), $\mathrm{Ph}_{4} \mathrm{P} / 3(5,67 \%), \mathrm{Me}_{4} \mathrm{~N} / 3(69 \%)$, and $\mathrm{Ph}_{3} \mathrm{P}\left(\mathrm{CH}_{2}\right)_{2} \mathrm{R}_{\mathrm{f}} / 2$ (73\%) or (2) $\mathrm{PhCH}_{2} \mathrm{P}\left(\left(\mathrm{CH}_{2}\right)_{3} \mathrm{R}_{\mathrm{f}}\right)_{3} / 2(14,39 \%), \mathrm{PhCH}_{2} \mathrm{P}\left(\left(\mathrm{CH}_{2}\right)_{3} \mathrm{R}_{\mathrm{f}}\right)_{3} / 3(15,63 \%)$, and PPN/2 (36\%). The educt $\left[\mathrm{Ph}_{3} \mathrm{P}\left(\mathrm{CH}_{2}\right)_{2} \mathrm{R}_{66}\right]_{2}\left[\mathrm{Fe}_{4} \mathrm{~S}_{4}\left(\mathrm{SC}\left(\mathrm{CH}_{3}\right)_{3}\right)_{4}\right]$ is in turn prepared from $\mathrm{FeCl}_{3}, \mathrm{HSC}\left(\mathrm{CH}_{3}\right)_{3} / \mathrm{CH}_{3} \mathrm{ONa}$, and $\left[\mathrm{Ph}_{3} \mathrm{P}-\right.$

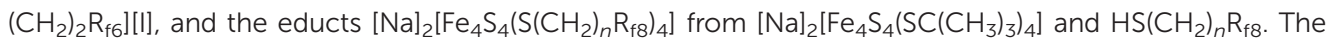
$\mathrm{SCH}_{2}{ }^{1} \mathrm{H}$ and ${ }^{13} \mathrm{C}$ NMR signals of these paramagnetic salts appear 8.7-10.3 and 32.3-34.9 ppm downfield from those of the corresponding thiols, but the chemical shifts of other signals are nearly normal. The UV-visible spectra show bands similar to those of non-fluorous analogs (290-298 nm and 406-415 nm; $\varepsilon=25700$ and $19200 \mathrm{M}^{-1} \mathrm{~cm}^{-1}$ for 5 ). The singly fluorous salts are soluble in organic solvents of moderate polarity, but not in fluorous solvents. The doubly fluorous salts 14, 15 are soluble in all fluorous solvents assayed, with partition coefficients of $>99.65:<0.35\left(\mathrm{CF}_{3} \mathrm{C}_{6} \mathrm{~F}_{11} /\right.$ toluene) and 93.2-93.1:6.9-6.8 (FC-72/THF). Cyclic voltammograms carried out using a platinum working microelectrode show that $\mathbf{4}$ is $0.08 \mathrm{~V}$ thermodynamically easier to reduce than $\mathbf{5}$.

\section{Introduction}

Iron/sulfur clusters are pervasive throughout biology, ${ }^{1}$ and approximately cubic $\mathrm{Fe}_{4} \mathrm{~S}_{4}$ systems featuring four iron bound thiolate ligands constitute one of the most prominent classes. ${ }^{2}$ During the sixties and seventies, syntheses of model compounds of the formula $n \mathrm{Q}^{+}\left[\mathrm{Fe}_{4} \mathrm{~S}_{4}(\mathrm{SR})_{4}\right]^{n-}$ were developed, with $\mathrm{Q}^{+}$typically an alkali metal, ammonium, or phosphonium cation. ${ }^{2 a, 3-5}$ Their "electron reservoir" properties were studied in detail; species could be generated in five redox states, with $n=0$ (4Fe(III)), 1 (3Fe(III)/1Fe(II)), 2 (2Fe(III)/2Fe(II)), 3 (1Fe(III)/ $3 \mathrm{Fe}(\mathrm{II}))$, and $4(4 \mathrm{Fe}(\mathrm{II})){ }^{6}$ Spectroscopic features were carefully compared with those of related iron-sulfur proteins, $^{7}$ and a

\footnotetext{
${ }^{a}$ Department of Chemistry, Texas A\&M University, P.O. Box 30012, College Station, Texas 77842-3012, USA. E-mail: gladysz@mail.chem.tamu.edu

${ }^{b}$ Department of Chemistry, The University of Texas at Austin, Austin, Texas 78712, USA.E-mail: bholiday@cm.utexas.edu

${ }^{c}$ Department of Chemistry, Texas A\&M University at Qatar, P.O. Box 23874, Doha, Qatar.E-mail: bazzi@tamu.edu

$\dagger$ Electronic supplementary information (ESI) available: Representative NMR and UV-visible spectra. See DOI: 10.1039/c5dt01959a

$¥$ Present address: School of Chemistry, Chemical Engineering and Life Science, Wuhan University of Technology, 205 Luoshi Road, Wuhan 430070, China.
}

number of complexes were tested as components of functional models for various metalloenzymes. ${ }^{8}$

More recently, analogs in which the thiolates have been replaced by cyanide or "modern" $\mathrm{N}$-heterocyclic carbene ligands, $n \mathrm{Q}^{+}\left[\mathrm{Fe}_{4} \mathrm{~S}_{4}(\mathrm{CN})_{4}\right]^{n-}$ or $\left[\mathrm{Fe}_{4} \mathrm{~S}_{4}(\mathrm{NHC})_{4}\right]^{n-}$, have been reported. ${ }^{9,10}$ Consistent with the markedly different electronic properties of these ligands, the redox potentials shift dramatically, allowing the first isolations of "all ferrous" (4Fe(II)) clusters. This proved of special interest in view of evidence supporting an all ferrous iron/sulfur assembly in one of the two nitrogenaese proteins from Azotobacter vinelandii. ${ }^{11}$

Horváth, Rábai, our group, and many others have demonstrated that by introducing appropriate numbers of perfluoroalkyl groups $\left(\left(\mathrm{CF}_{2}\right)_{n-1} \mathrm{CF}_{3}=\mathrm{R}_{\mathrm{fn}}\right)$ of sufficient lengths, a variety of neutral molecules can be rendered soluble in nonpolar fluorous liquid phases, such as perfluorohexanes (FC-72). ${ }^{12}$ We have also shown that many ionic compounds, ${ }^{13}$ such as organic ammonium and phosphonium salts, as well as salts of inorganic polycations, ${ }^{14}$ can similarly be rendered soluble in fluorous phases. ${ }^{15,16}$ As such, it was natural to speculate whether the right combination of fluorous thiolate substituents and fluorous cations might render salts of the type $n \mathrm{Q}^{+}$ $\left[\mathrm{Fe}_{4} \mathrm{~S}_{4}(\mathrm{SR})_{4}\right]^{n-}$ soluble in fluorous media. In addition to this 
"phase shift", the thiolate based $\mathrm{R}_{\mathrm{f} n}$ moieties should also shift redox potentials, rendering reductions to ferrous rich states thermodynamically more favorable.

This line of investigation could have practical aspects. Although "nothing sticks to Teflon", small nonpolar molecules retain appreciable solubilities in fluorous solvents. ${ }^{15}$ Such fluids possess very low "cavitation energies", 17 creating space for small nonpolar guests but offering little in the way of enthalpically favorable interactions. For this reason, various perfluorinated media have been studied as oxygen carriers or blood substitutes, and even commercialized for this purpose. ${ }^{18}$ In this context, the central role of iron/sulfur clusters in nitrogen fixation is well established. ${ }^{19}$ The reactants nitrogen and hydrogen have, as with oxygen, appreciable solubilities in fluorous solvents, as tabulated below. ${ }^{20,21}$ Hence, this represents a tantalizing but to our knowledge overlooked environment for nitrogen fixation. Furthermore, since the reduction products hydrazine and ammonia are highly polar, they should have very low solubilities in fluorous solvents and readily phase separate.

Accordingly, in this paper we report convenient syntheses of the paramagnetic $2 \mathrm{Fe}(\mathrm{III}) / 2 \mathrm{Fe}$ (II) iron/sulfur cluster salts $[\mathrm{Q}]_{2}\left[\mathrm{Fe}_{4} \mathrm{~S}_{4}\left(\mathrm{~S}\left(\mathrm{CH}_{2}\right)_{n} \mathrm{R}_{\mathrm{f} 8}\right)_{4}\right]$, which feature a fluorous dianion and cations that exhibit a range of fluorophilicities: non-fluorous, "light fluorous", and "heavy fluorous". ${ }^{22}$ Their spectroscopic and phase properties are investigated, and redox characteristics analyzed, thus providing a solid baseline for future applications of these unique complexes.

\section{Results}

\section{Syntheses of fluorous iron/sulfur clusters}

The $t$-butylthiolate substituted iron/sulfur cluster salts $\left[\mathrm{Ph}_{4} \mathrm{P}\right]_{2}\left[\mathrm{Fe}_{4} \mathrm{~S}_{4}\left(\mathrm{SC}\left(\mathrm{CH}_{3}\right)_{3}\right)_{4}\right]$ (1) and $\left[\mathrm{Me}_{4} \mathrm{~N}\right]_{2}\left[\mathrm{Fe}_{4} \mathrm{~S}_{4}\left(\mathrm{SC}\left(\mathrm{CH}_{3}\right)_{3}\right)_{4}\right]$ (2) were prepared by literature procedures as depicted in Scheme $1 .^{3}$ These compounds have been shown to react with slight excesses of thiols (HSR) to give substitution products of the formula $[\mathrm{Q}]_{2}\left[\mathrm{Fe}_{4} \mathrm{~S}_{4}(\mathrm{SR})_{4}\right]$. ${ }^{4,5}$ Accordingly, the fluorous aliphatic thiols $\mathrm{HS}\left(\mathrm{CH}_{2}\right)_{n} \mathrm{R}_{\mathrm{f8}}(3 \mathbf{a}, n=2 ; 3 \mathbf{b}, n=3)$, which feature two and three "methylene spacer" segments, were synthesized as previously described. ${ }^{23}$
As shown in Scheme 1, a $\mathrm{CH}_{3} \mathrm{CN}$ solution of the phosphonium salt 1 was treated with the "two spacer" thiol 3a (6.25 equiv.). Workup gave the target cluster $\left[\mathrm{Ph}_{4} \mathrm{P}\right]_{2}\left[\mathrm{Fe}_{4} \mathrm{~S}_{4}\right.$ $\left.\left(\mathrm{S}\left(\mathrm{CH}_{2}\right)_{2} \mathrm{R}_{\mathrm{f8}}\right)_{4}\right](4)$ as a dark brown solid in $67 \%$ yield. A similar reaction with the "three spacer" thiol $3 \mathbf{b}$ (5.0 equiv.) gave the

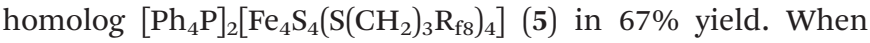
the ammonium salt $\mathbf{2}$ and $\mathbf{3 b}$ were similarly reacted,

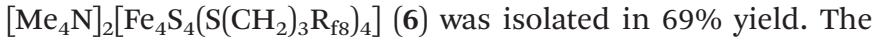
characterization of these complexes is described below.

Salts with both fluorous anions and cations were sought. Efforts began with a sequence similar to that used to prepare 1 and 2 (Scheme 1). Thus, an anhydrous $\mathrm{CH}_{3} \mathrm{OH}$ solution of $\mathrm{CH}_{3} \mathrm{ONa}$ and $\mathrm{HSC}\left(\mathrm{CH}_{3}\right)_{3}$ (ca. 4 equiv. each; the latter also serves as a reductant) was treated with anhydrous $\mathrm{FeCl}_{3}$ (1.0 equiv.) and then elemental sulfur (1.0 equiv.). After a filtration step (to give a solution of a disodium salt described below), the previously reported "light fluorous" phosphonium salt $\left[\mathrm{Ph}_{3} \mathrm{P}\left(\mathrm{CH}_{2}\right)_{2} \mathrm{R}_{\mathrm{f} 6}\right][\mathrm{I}]\left(7 ;^{24} 0.75\right.$ equiv. or a 1.5 fold excess $)$ was added. Workup gave crude $\left[\mathrm{Ph}_{3} \mathrm{P}\left(\mathrm{CH}_{2}\right)_{2} \mathrm{R}_{\mathrm{f} 6}\right]_{2}\left[\mathrm{Fe}_{4} \mathrm{~S}_{4}\left(\mathrm{SC}\left(\mathrm{CH}_{3}\right)_{3}\right)_{4}\right]$ (8) as a black solid in ca. 25\% yield. The NMR spectrum indicated a purity of $c a .90 \%$, which despite extensive attempts could not be improved. However, this sufficed for subsequent chemistry.

Next, a $\mathrm{CH}_{3} \mathrm{CN}$ solution of $\mathbf{8}$ was treated with the "two spacer" thiol $\mathrm{HS}\left(\mathrm{CH}_{2}\right)_{2} \mathrm{R}_{\mathrm{f} 8}$ (3a, 6.0 equiv.). Workup as above gave the target doubly fluorous salt $\left[\mathrm{Ph}_{3} \mathrm{P}\left(\mathrm{CH}_{2}\right)_{2} \mathrm{R}_{\mathrm{f} 6}\right]_{2}\left[\mathrm{Fe}_{4} \mathrm{~S}_{4^{-}}\right.$ $\left.\left.\left(\mathrm{S}_{(} \mathrm{CH}_{2}\right)_{2} \mathrm{R}_{\mathrm{f} 8}\right)_{4}\right](9)$ as a dark brown solid in $73 \%$ yield. This sample was pure by NMR, although the carbon microanalysis was slightly high (31.69\% vs. $31.02 \%$ calcd).

Approaches to doubly fluorous systems involving cation metatheses were then investigated. First, an anhydrous $\mathrm{CH}_{3} \mathrm{OH}$ solution of $\mathrm{CH}_{3} \mathrm{ONa}, \mathrm{HSC}\left(\mathrm{CH}_{3}\right)_{3}$ ( $c a .4$ equiv. each), $\mathrm{FeCl}_{3}$ (1.0 equiv.), and elemental sulfur (1.0 equiv.) were combined as in Scheme 1. An intermediate workup gave the crude $t$-butylthiolate substituted disodium salt $[\mathrm{Na}]_{2}\left[\mathrm{Fe}_{4} \mathrm{~S}_{4}(\mathrm{SC}-\right.$ $\left.\left.\left(\mathrm{CH}_{3}\right)_{3}\right)_{4}\right](\mathbf{1 0})$ as a black solid. Others have similarly generated this species and exchanged the thiolate ligands in situ. ${ }^{3}$ Thus, as shown in Scheme 2, the fluorous thiols 3a,b (ca. 4 equiv.) were added, and workups gave the new disodium salts $[\mathrm{Na}]_{2}\left[\mathrm{Fe}_{4} \mathrm{~S}_{4}\left(\mathrm{~S}\left(\mathrm{CH}_{2}\right)_{n} \mathrm{R}_{\mathrm{f} 8}\right)_{4}\right](11, n=2,81 \% ; 12, n=3,50 \%)$. The former could only be obtained in crude form, but the latter was pure by NMR. Complex $\mathbf{1 1}$ could also be prepared in com-

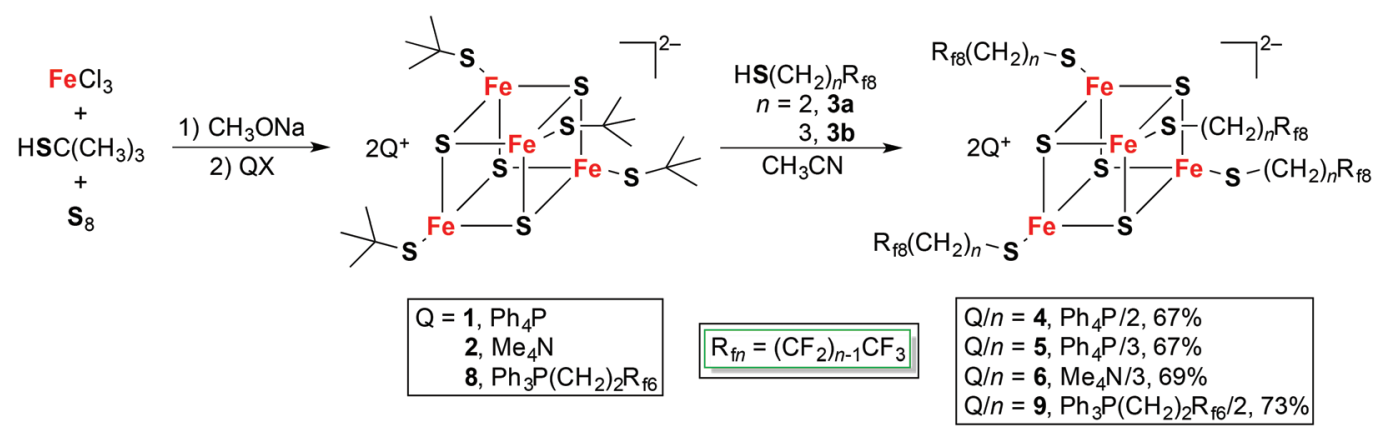

Scheme 1 Syntheses of fluorous iron/sulfur clusters by thiolate ligand exchange. 


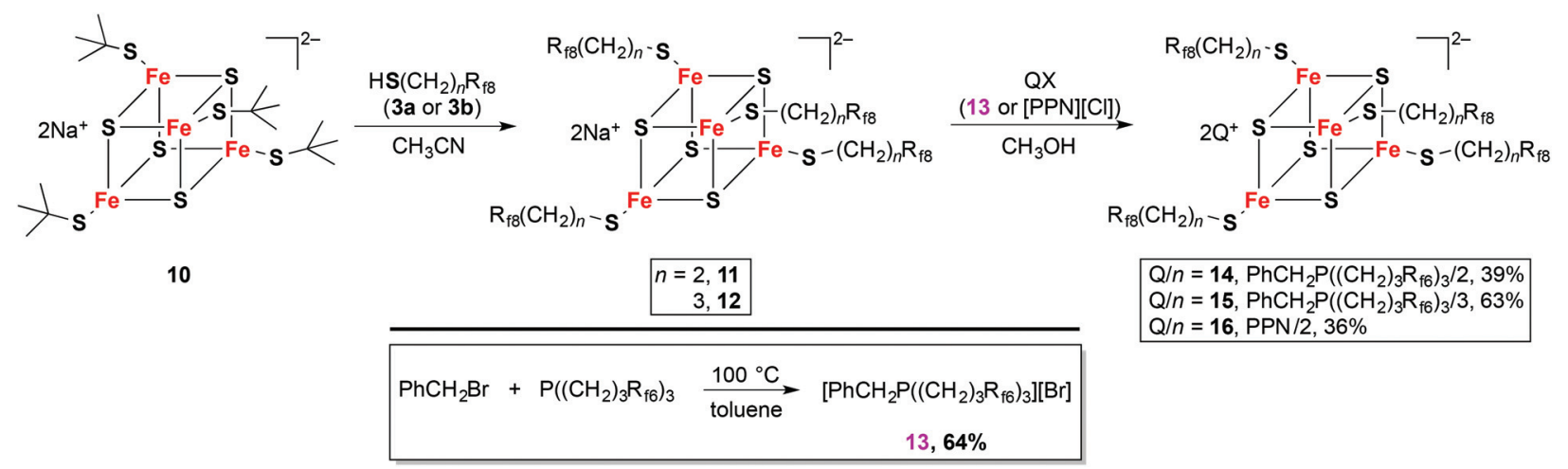

Scheme 2 Syntheses of fluorous iron/sulfur clusters by cation exchange.

parable yield and purity in a single step from $\mathrm{FeCl}_{3}$, a $\mathrm{CH}_{3} \mathrm{OH}$ solution of $\mathrm{CH}_{3} \mathrm{ONa}$, elemental sulfur, and $3 \mathbf{a}$ in place of $\mathrm{HSC}\left(\mathrm{CH}_{3}\right)_{3}$.

Next, a "heavy fluorous" phosphonium salt was sought. Thus, as depicted in Scheme 2 (bottom), the known "heavy fluorous" phosphine $\mathrm{P}\left(\left(\mathrm{CH}_{2}\right)_{3} \mathrm{R}_{\mathrm{f} 6}\right)_{3}{ }^{25}$ and benzyl bromide were reacted in toluene at $100{ }^{\circ} \mathrm{C}$. Workup gave the new salt $\left[\mathrm{PhCH}_{2} \mathrm{P}\left(\left(\mathrm{CH}_{2}\right)_{3} \mathrm{R}_{\mathrm{f} 6}\right)_{3}\right][\mathrm{Br}](\mathbf{1 3})$ as a colorless sticky but analytically pure liquid in $64 \%$ yield. The fluorous disodium salts 11 and 12 were then combined with 13 (2.0 equiv.) in $\mathrm{MeOH}$. Workups gave the dark brown doubly fluorous salts $\left[\mathrm{PhCH}_{2} \mathrm{P}\right.$ $\left.\left(\left(\mathrm{CH}_{2}\right)_{3} \mathrm{R}_{\mathrm{f6}}\right)_{3}\right]_{2}\left[\mathrm{Fe}_{4} \mathrm{~S}_{4}\left(\mathrm{~S}\left(\mathrm{CH}_{2}\right)_{2} \mathrm{R}_{\mathrm{f} 8}\right)_{4}\right] \quad$ (14) and $\left[\mathrm{PhCH}_{2} \mathrm{P}-\right.$

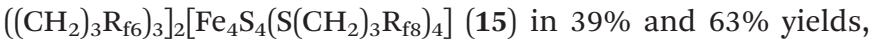
respectively. The lower yield of the former can be attributed to the lower purity of the precursor 11.

Extensive attempts were made to grow single crystals of the preceding salts. However, in only one case was a crystal obtained that diffracted. The perfluoroalkyl chains were hope- lessly disordered, although refinement unambiguously located the $(\mathrm{FeS})_{4} \mathrm{~S}_{4}$ core and two $\mathrm{Ph}_{4} \mathrm{P}^{+}$cations. In another effort to obtain a crystalline sample, crude $\mathbf{1 1}$ and $[\mathrm{PPN}][\mathrm{Cl}]^{26}(\mathrm{PPN}=$ $\mathrm{Ph}_{3} \mathrm{P} \cdots \mathrm{N} \cdots \mathrm{PPh}_{3}$ ) were combined in degassed MeOH. Workup gave the salt $[\mathrm{PPN}]_{2}\left[\mathrm{Fe}_{4} \mathrm{~S}_{4}\left(\mathrm{~S}\left(\mathrm{CH}_{2}\right)_{2} \mathrm{R}_{\mathrm{f} 8}\right)_{4}\right]$ (16) as dark brown plates in $36 \%$ yield. However, crystallization again failed.

\section{Properties of fluorous iron/sulfur clusters}

The fluorous iron/sulfur clusters 4-6, 9 and 14-16 were characterized by a variety of techniques, but due to their lower purities, the synthetic intermediates $\mathbf{8}$ and $\mathbf{1 1}$ were not further examined. The doubly fluorous salts $(\mathbf{1 4}, \mathbf{1 5})$ gave satisfactory microanalyses. However, the carbon values of other salts were slightly off (0.67-0.70\% for 4 and 9), and in two cases the sulfur values similarly deviated $(\mathbf{1 2}, \mathbf{1 6})$.

As summarized in Table 1, solubilities were qualitatively surveyed. All of the singly fluorous salts $(\mathbf{4 - 6}, \mathbf{1 6})$ were soluble in organic solvents of moderate polarity, but not in fluorous

Table 1 Qualitative solubility data for the fluorous iron/sulfur clusters (room temperature) ${ }^{a}$

\begin{tabular}{|c|c|c|c|c|c|c|c|}
\hline \multirow[b]{2}{*}{ Solvent } & \multicolumn{7}{|l|}{ Complex } \\
\hline & 4 & 5 & 6 & 9 & 14 & 15 & 16 \\
\hline $\mathrm{CH}_{3} \mathrm{OH}$ & Soluble & Soluble & Soluble & Soluble & Insoluble & Insoluble & Soluble \\
\hline Acetone & Highly soluble & Highly soluble & Highly soluble & Highly soluble & Slightly soluble & Slightly soluble & Highly soluble \\
\hline $\mathrm{CH}_{3} \mathrm{CN}$ & Highly soluble & Highly soluble & Highly soluble & Highly soluble & Slightly soluble & Slightly soluble & Highly soluble \\
\hline DMSO & Soluble & Soluble & Soluble & Slightly soluble & Insoluble & Insoluble & Soluble \\
\hline $\mathrm{DMF}$ & Soluble & Soluble & Soluble & Soluble & Slightly soluble & Slightly soluble & Soluble \\
\hline EtOAc & Soluble & Soluble & Slightly soluble & Slightly soluble & Slightly soluble & Slightly soluble & Slightly soluble \\
\hline $\mathrm{CHCl}_{3}$ & Soluble & Soluble & Insoluble & Soluble & Insoluble & Insoluble & Soluble \\
\hline $\mathrm{CH}_{2} \mathrm{Cl}_{2}$ & Highly soluble & Highly soluble & Slightly soluble & Soluble & Insoluble & Insoluble & Highly soluble \\
\hline $\mathrm{Et}_{2} \mathrm{O}$ & Soluble & Soluble & Insoluble & Insoluble & Slightly soluble & Slightly soluble & Soluble \\
\hline $\mathrm{THF}$ & Soluble & Soluble & Soluble & Soluble & Soluble & Soluble & Highly soluble \\
\hline $\mathrm{C}_{6} \mathrm{H}_{6}$ & Slightly soluble & Slightly soluble & Insoluble & Insoluble & Insoluble & Insoluble & Soluble \\
\hline Toluene & Slightly soluble & Slightly soluble & Insoluble & Insoluble & Insoluble & Insoluble & Soluble \\
\hline Hexane & Insoluble & Insoluble & Insoluble & Insoluble & Insoluble & Insoluble & Insoluble \\
\hline $\mathrm{FC}-70^{b}$ & Insoluble & Insoluble & Insoluble & Insoluble & Soluble & Soluble & Insoluble \\
\hline $\mathrm{FC}-72^{c}$ & Insoluble & Insoluble & Insoluble & Insoluble & Soluble & Soluble & Insoluble \\
\hline $\mathrm{CF}_{3} \mathrm{C}_{6} \mathrm{~F}_{11}^{d}$ & Insoluble & Insoluble & Insoluble & Insoluble & Soluble & Soluble & Insoluble \\
\hline $\mathrm{FC}-75^{e}$ & Insoluble & Insoluble & Insoluble & Insoluble & Soluble & Soluble & Insoluble \\
\hline
\end{tabular}

${ }^{a} \mathrm{~N}_{2}$ atmosphere. ${ }^{b}\left(\mathrm{C}_{5} \mathrm{~F}_{11}\right)_{3} \mathrm{~N} .{ }^{c}$ Perfluorohexanes. ${ }^{d}$ Perfluoro(methylcyclohexane). ${ }^{e}$ Perfluoro(2-butyltetrahydrofuran). 
solvents. Those with non-fluorous phosphonium cations $(\mathbf{4}, \mathbf{5}$, 16) exhibited some solubility in less polar solvents such as $\mathrm{Et}_{2} \mathrm{O}$, benzene, and toluene, but the tetraethylammonium salt (6) did not. In contrast, the two doubly fluorous salts with "heavy fluorous" cations $(\mathbf{1 4}, \mathbf{1 5})$ were soluble in all of the fluorous solvents assayed, and much less soluble in common organic solvents with the exception of THF. Complex 9, with a "light fluorous" cation, was insoluble in fluorous solvents and quite variable with respect to organic solvents.

Fluorous/organic partition coefficients for 14 and 15 were probed by UV-visible spectroscopy as described in the Experimental section. Neither 14 nor 15 showed a detectable level of solubility in toluene. Hence, it was only possible to set a boundary value of $>99.65:<0.35$ for the $\mathrm{CF}_{3} \mathrm{C}_{6} \mathrm{~F}_{11} /$ toluene partition coefficients (the most frequently assayed solvent combination in the literature). ${ }^{16}$ However, due to the greater solubilities of 14 and 15 in THF, FC-72/THF partition coefficients could be measured. As is not surprising given that $\mathbf{1 4}$ and $\mathbf{1 5}$ differ by only four methylene groups, they were identical within experimental error (93.2: 6.8 and $93.1: 6.9)$.

With all complexes, a full set of ${ }^{1} \mathrm{H}$ and ${ }^{13} \mathrm{C}$ NMR signals could be observed, and representative spectra are provided in the ESI. $\dagger$ Consistent with much literature precedent, ${ }^{4 h, 5 b, 6 d, e, 7 c}$ the $\mathrm{FeSCH}_{2}{ }^{1} \mathrm{H}$ signals were shifted markedly downfield to $\delta$ 12.9-11.4 ppm $\left(\mathrm{CD}_{2} \mathrm{Cl}_{2}\right.$, acetone- $\mathrm{d}_{6}$, or THF- $\left.\mathrm{d}_{8}\right)$, as opposed to $\delta$ 2.61-2.75 ppm $\left(\mathrm{CDCl}_{3}\right)$ for the $\mathrm{HSCH}_{2}$ signals of the free thiols. ${ }^{23}$ In contrast, the $\mathrm{FeSCH}_{2} \mathrm{CH}_{2} \mathrm{R}_{\mathrm{f} 8}$ signals of the "two methylene spacer" complexes $\mathbf{4}$ and $\mathbf{1 6}$ appeared at $\delta$ 2.29-2.46 ppm, essentially identical to the free thiol $\mathrm{HSCH}_{2} \underline{\mathrm{CH}}_{2} \mathrm{R}_{\mathrm{f} 8}$ signal $\left(\begin{array}{lll}\delta & 2.4 & \mathrm{ppm}\end{array}\right) .{ }^{23 b}$ The $\mathrm{FeSCH}_{2} \mathrm{CH}_{2}$ signals were not resolved or unambiguously assignable in the other compounds, in part because many couplings exhibited by the free thiols could no longer be observed. However, their chemical shifts could be bounded within a slightly expanded range.

All ${ }^{13} \mathrm{C}$ NMR spectra were recorded with both ${ }^{1} \mathrm{H}$ and ${ }^{19} \mathrm{~F}$ decoupling, simplifying analyses. The $\mathrm{R}_{\mathrm{f} 8}$ segments exhibited chemical shifts very close to those of related diamagnetic compounds, with values ranging from $\delta 125.7$ to $108.4 \mathrm{ppm}$ in accord with previous compilations. ${ }^{27}$ The $\mathrm{FeSCH}_{2}{ }^{13} \mathrm{C}$ signals in complexes with $\mathrm{FeS}\left(\mathrm{CH}_{2}\right)_{2} \mathrm{R}_{\mathrm{f} 8}$ linkages appeared at $\delta$ 75.7-71.8 ppm, and those in complexes with $\mathrm{FeS}\left(\mathrm{CH}_{2}\right)_{3} \mathrm{R}_{\mathrm{f} 8}$ linkages appeared at $\delta$ 58.7-56.1 ppm. These assignments, which represent downfield shifts of $\delta 32.3-34.9$ ppm from the free thiols, ${ }^{23}$ are based upon similar shifts described for nonfluorous analogs earlier. ${ }^{28}$ The ${ }^{19} \mathrm{~F}$ NMR spectra showed normal chemical shift patterns for the $\mathrm{CF}_{2}$ and $\mathrm{CF}_{3}$ groups. ${ }^{27}$

Given the solubility data in Table 1, it was not possible to measure UV-visible spectra in a single solvent. Complex 4 showed two absorptions $\left(\mathrm{CH}_{3} \mathrm{CN}\right)$ at 294 and $406 \mathrm{~nm}(\varepsilon=$ 22200 and $16000 \mathrm{M}^{-1} \mathrm{~cm}^{-1}$ ), with the latter appearing as a peak on the broader former band as it tailed into the visible. These bands ranged from 290 to $298 \mathrm{~nm}$ and 406 to $415 \mathrm{~nm}$ with 5, 6, 9 and 14-16 $\left(\mathrm{CH}_{3} \mathrm{CN}\right.$ or THF), and representative spectra are provided in the ESI. $\dagger$ For comparison, the UVvisible spectrum of $t$-butylthiolate substituted $\left[n-\mathrm{Bu}_{4} \mathrm{~N}\right]_{2^{-}}$

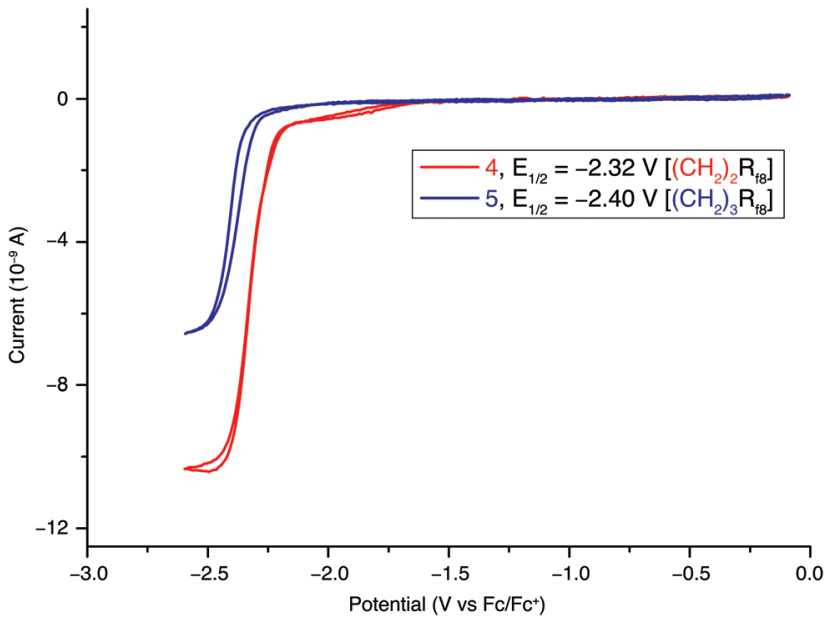

Fig. 1 Cyclic voltammograms of 4 and 5 in DMF $\left(5.0 \times 10^{-4} \mathrm{M}\right)$ containing $\left[n-\mathrm{Bu}_{4} \mathrm{~N}\right]\left[\mathrm{B}\left(\mathrm{C}_{6} \mathrm{~F}_{5}\right)_{4}\right]$ supporting electrolyte $\left(3.0 \times 10^{-3} \mathrm{M}\right)$ using a platinum working microelectrode $(10 \mu \mathrm{M}$ diameter $)$ and recorded at ambient temperature and $100 \mathrm{mV} \mathrm{s}^{-1}$.

$\left[\mathrm{Fe}_{4} \mathrm{~S}_{4}\left(\mathrm{SC}\left(\mathrm{CH}_{3}\right)_{3}\right)_{4}\right]$ is slightly red shifted, with bands in DMF at 303 and $417 \mathrm{~nm}\left(\varepsilon=21800\right.$ and $\left.16700 \mathrm{M}^{-1} \mathrm{~cm}^{-1}\right) \cdot{ }^{6 a, b, 7 b} \mathrm{In}$ contrast, in fluorous solvents, 14 and 15 exhibited a single absorption (FC-72: 14, $415 \mathrm{~nm}, \varepsilon=11700 \mathrm{M}^{-1} \mathrm{~cm}^{-1} ; \mathbf{1 5}$, $422 \mathrm{~nm}, \varepsilon=16900 \mathrm{M}^{-1} \mathrm{~cm}^{-1}$ ).

A final question concerns the degree to which the redox properties of these iron/sulfur clusters are influenced by the electron withdrawing $\mathrm{R}_{\mathrm{f} 8}$ groups. It has been established that ca. six methylene spacers are needed for "complete" insulation. ${ }^{29}$ Thus, cyclic voltammograms were sought. However, when DMF and $\mathrm{CH}_{3} \mathrm{CN}$ solutions of 4-6 or 9 were treated with the supporting electrolyte $\left[n-\mathrm{Bu}_{4} \mathrm{~N}\right]\left[\mathrm{PF}_{6}\right](0.1 \mathrm{M}$ in DMF or $\mathrm{CH}_{3} \mathrm{CN}$ ), dark precipitates formed, together with yellow supernatants. Analogous behavior was not observed with the $t$-butylthiolate substituted analog $\left[\mathrm{Ph}_{4} \mathrm{P}\right]_{2}\left[\mathrm{Fe}_{4} \mathrm{~S}_{4}\left(\mathrm{SC}\left(\mathrm{CH}_{3}\right)_{3}\right)_{4}\right](\mathbf{1})$, which has an extensively studied electrochemistry. Thus, this behavior was tentatively attributed to an irreversible condensation to an insoluble bulk $\mathrm{Fe}_{x} \mathrm{~S}_{y}$ system. Such cluster aggregation processes have been documented previously. ${ }^{30}$

A variety of other electrolytes were screened, including several with very poorly nucleophilic tetraarylborate anions $\left(\mathrm{Ar}=\mathrm{C}_{6} \mathrm{~F}_{5}, 3,5-\mathrm{C}_{6} \mathrm{H}_{3}\left(\mathrm{CF}_{3}\right)_{2}\right)$ but always with the same outcome. However, when cyclic voltammograms are recorded using microelectrodes, electrolyte concentrations can be greatly reduced. ${ }^{31}$ Thus, as depicted in Fig. 1 , when a $10 \mu \mathrm{M}$ platinum working microelectrode was employed, DMF solutions of 4 and $5\left(5.0 \times 10^{-4} \mathrm{M}\right)$ charged with much lower electrolyte concentrations $\left(3.0 \times 10^{-3} \mathrm{M}\left[n-\mathrm{Bu}_{4} \mathrm{~N}\right]\left[\mathrm{B}\left(\mathrm{C}_{6} \mathrm{~F}_{5}\right)_{4}\right]\right)$ exhibited well behaved, chemically reversible reductions. ${ }^{32}$ As would be expected, 4, with a two methylene spacer, proved thermodynamically easier to reduce than $\mathbf{5}$, with a three methylene spacer $\left(E_{1 / 2}-2.32 v s\right.$. $-2.40 \mathrm{~V} v s$. ferrocene/ferrocenium). No oxidations were observed in anodic scans out to $-0.08 \mathrm{~V}$. 


\section{Discussion}

Schemes 1 and 2 establish the ready availability of fluorous

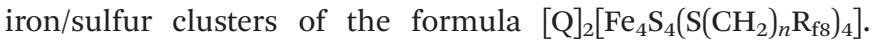
Compounds in which only the dianion is fluorous preferentially dissolve in organic solvents, whereas those that also incorporate "heavy fluorous" cations become fluorophilic. Despite the very low polarity of fluorous solvents, increasing numbers of ionic compounds are being realized that exhibit appreciable solubility. ${ }^{13 d}$ Some have proven to be catalysts for reactions in fluorous phases. ${ }^{13 b-d}$

One motivation for the present study has been the possibility of carrying out nitrogen fixation in a fluorous phase. Most nitrogenaeses are comprised of an iron protein containing $\mathrm{Fe}_{4} \mathrm{~S}_{4}$ clusters and an iron/molybdenum protein featuring a structurally more complex cluster. ${ }^{1,11}$ One attraction of fluorous phases is their high solubilities for the diatomic gases oxygen, nitrogen, and hydrogen, ${ }^{20,21}$ the basis for which is noted above. There are several commonly employed measures of solubility, three of which are provided in Table 2 . The most important are the mol fraction of a gas in a saturated solution (the data compiled in most reference books), and the molarity (the important quantity for rate expressions). With respect to the latter, the solubility of hydrogen in fluorous solvents is approximately twice that in THF, and the solubility of nitrogen is approximately 2.5 times that in THF. The solubility increase with oxygen is intermediate. When solubilities in mol fractions are compared, the differences are much greater, due (as worked through elsewhere $)^{15}$ to the higher molecular weights of fluorous solvents $v s$. THF.

Table 2 Solubilities of oxygen, hydrogen, and nitrogen in fluorous solvents and $\mathrm{THF}^{\mathrm{a}}$

\begin{tabular}{|c|c|c|c|}
\hline Solubility & $\mathrm{CF}_{3} \mathrm{C}_{6} \mathrm{~F}_{11}^{b}$ & $\mathrm{C}_{7} \mathrm{~F}_{16}{ }^{c}$ & $\mathrm{THF}^{d}$ \\
\hline $\mathrm{O}_{2}$ (mol fraction) & $0.00456^{e, f}$ & $0.00555^{e, f}$ & $0.000816^{e}$ \\
\hline $\mathrm{O}_{2}$ (mol ratio) & $0.00458^{g}$ & 0.00558 & 0.000817 \\
\hline $\mathrm{O}_{2}\left(\mathrm{~mol} \mathrm{~L}^{-1}\right)$ & 0.0234 & 0.0251 & $0.0101^{g}$ \\
\hline $\mathrm{H}_{2}$ (mol fraction) & $0.0012^{h}$ & $0.0014007^{i}$ & $0.000274^{i}$ \\
\hline $\mathrm{H}_{2}$ (mol ratio) & $0.0012^{g}$ & 0.0014027 & 0.000274 \\
\hline $\mathrm{H}_{2}\left(\mathrm{~mol} \mathrm{~L}^{-1}\right)$ & 0.0061 & 0.0063071 & $0.00338^{g}$ \\
\hline $\mathrm{N}_{2}$ (mol fraction) & $0.00331^{j}$ & $0.00390^{j}$ & $0.000521^{j}$ \\
\hline $\mathrm{N}_{2}$ (mol ratio) & 0.00332 & 0.00392 & 0.000521 \\
\hline $\mathbf{N}_{2}\left(\operatorname{mol~L}^{-1}\right)$ & 0.0169 & 0.0176 & 0.00643 \\
\hline
\end{tabular}

${ }^{a}$ Data were, unless noted, obtained at $T=298.15 \mathrm{~K}$ with a partial pressure $\left(\mathrm{O}_{2}, \mathrm{H}_{2}\right.$, or $\left.\mathrm{N}_{2}\right) P=101.325 \mathrm{kPa} .{ }^{b}$ Perfluoromethylcyclohexane; $1.787 \mathrm{~g} \mathrm{~mL}^{-1}$ at $298.15 \mathrm{~K}$. ${ }^{c}$ Perfluoroheptane; $1.745 \mathrm{~g} \mathrm{~mL}^{-1}$ at $298.15 \mathrm{~K} .{ }^{d} \mathrm{THF}=$ tetrahydrofuran; $0.889 \mathrm{~g} \mathrm{~mL}^{-1}$ at $298.15 \mathrm{~K} .{ }^{e}$ IUPAC Solubility Data Series, ed. R. Battino, Pergamon, New York, 1981, vol. 7. ${ }^{f}$ For this determination, the total pressure is $101.325 \mathrm{kPa} .{ }^{g}$ There is a slight error in this value in an earlier version of this table: J. A. Gladysz, C. Emnet, Fluorous Solvents and Related Media, in Handbook of Fluorous Chemistry, ed. J. A. Gladysz, D. P. Curran and I. T. Horváth, Wiley/VCH, Weinheim, 2004, p. 17. ${ }^{h}$ C. R. Patrick, in Preparation, Properties, and Industrial Applications of Organofluorine Compounds, ed. R. E. Banks, Ellis Horwood, New York, 1982, p. 53. ${ }^{i}$ IUPAC Solubility Data Series, ed. C. L. Young, Pergamon, New York, 1981, vol. 5/6. ${ }^{j}$ R. Battino, T. R. Rettich, T. Tominaga, J. Phys. Chem. Ref. Data, 1984, 13, 563-600.
Of course, achieving abiological nitrogen fixation will require more than just iron/sulfur clusters, so much more fundamental work remains to be done. Nonetheless, the high polarity of the product ammonia should promote phase separation from the fluorous medium, facilitating catalyst separation and recovery. If the reaction pathways involve polar intermediates, such as hydrazine, these also may phase separate, leading to unconventional product distributions.

However, given the experimental difficulties with cyclic voltammograms noted above, the title claim of "redox shifted" iron/sulfur clusters remains only partially quantified. Regardless, this is a certainty from well established inductive effects. $^{29}$ Iron/sulfur clusters with fluorous thiolates will be electron deficient and therefore thermodynamically easier to reduce. This is reflected by less negative $E_{1 / 2}$ value of 4 $(-2.32 \mathrm{~V})$ versus $5(-2.40 \mathrm{~V})$, indicating a more facile reduction, consistent with the decreased methylene spacer length.

The title compounds can be compared to the phenylthiolate and pentafluorophenylthiolate substituted clusters $[\mathrm{Q}]_{2}\left[\mathrm{Fe}_{4} \mathrm{~S}_{4}\left(\mathrm{SC}_{6} \mathrm{H}_{5}\right)_{4}\right]^{6 a}$ and $[\mathrm{Q}]_{2}\left[\mathrm{Fe}_{4} \mathrm{~S}_{4}\left(\mathrm{SC}_{6} \mathrm{~F}_{5}\right)_{4}\right]^{3 a}\left(\mathrm{Q}=\mathrm{Et}_{4} \mathrm{~N}\right.$ and $n-\mathrm{Bu}_{4} \mathrm{~N}$, respectively). Both of these undergo reversible one electron reductions, with the pentafluorophenylthiolate substituted complex proving $0.25 \mathrm{~V}$ easier to reduce $\left(\Delta E_{1 / 2}, \mathrm{DMF}\right){ }^{6 a}$ It should be emphasized in passing that molecules with pentafluorophenyl groups are not fluorous, ${ }^{22}$ as the polarizability of the $\pi$ cloud commonly leads to significant solubilities in organic solvents. However, both the phenylthiolate and pentafluorophenylthiolate substituted complexes could likely be rendered fluorous by appending sufficient numbers of $\mathrm{R}_{\mathrm{f} n}$ aryl substituents.

One obvious extension of this study would be to iron/sulfur clusters with $\mathrm{CH}_{2} \mathrm{R}_{\mathrm{f} n}$ and $\mathrm{SR}_{\mathrm{f} n}$ substituents (one or zero methylene spacers). Thiols of the formula $\mathrm{HSCH}_{2} \mathrm{R}_{\mathrm{f} n}$ are easily accessed with $n=1-3,{ }^{33}$ and higher homologs $(n=8)^{34}$ have been reported. However, to our knowledge spacerless fluorous thiols $\mathrm{HSR}_{\mathrm{f} n}$ are not yet available in preparatively useful quantities. Complexes in either of these series would be expected to be slightly more fluorophilic, and much more redox shifted (easier to reduce).

In summary, this study has established the ready availability of fluorous iron/sulfur clusters of the formula $[\mathrm{Q}]_{2}\left[\mathrm{Fe}_{4} \mathrm{~S}_{4}\left(\mathrm{~S}\left(\mathrm{CH}_{2}\right)_{n} \mathrm{R}_{\mathrm{f} 8}\right)_{4}\right]$, where $\mathrm{Q}$ is a (1) non-fluorous phosphonium or ammonium cation, (2) a "light fluorous" phosphonium cation, or (3) a "heavy fluorous" phosphonium salt. In general, the spectroscopic properties are very similar to those of the non-fluorous analogs. However, the phase and redox properties are significantly affected, both of which have the potential to open up new applications for these unusual analogs of metalloenzyme cofactors.

\section{Experimental section}

\section{General}

All reactions and workups were conducted under $\mathrm{N}_{2}$ atmospheres. Solvents were purified as follows: hexane, toluene, 
THF, $\mathrm{Et}_{2} \mathrm{O}$, and $\mathrm{CH}_{2} \mathrm{Cl}_{2}$ were dried and degassed using a Glass Contour Solvent System; acetone, DMSO, DMF, EtOAc, $\mathrm{CHCl}_{3}$, and benzene were distilled from $\mathrm{CaH}_{2}$ or $4 \AA$ molecular sieves (beads) under $\mathrm{N}_{2}$ atmospheres; $\mathrm{CH}_{3} \mathrm{CN}$ was distilled from $\mathrm{CaH}_{2}$ and $\mathrm{CH}_{3} \mathrm{OH}$ from sodium under $\mathrm{N}_{2}$ atmospheres; FC-72 (perfluorohexane), $\mathrm{CF}_{3} \mathrm{C}_{6} \mathrm{~F}_{11}$ (perfluoromethylcyclohexane), FC-70 $\left(\left(\mathrm{C}_{5} \mathrm{~F}_{11}\right)_{3} \mathrm{~N}\right)$, and FC-75 (perfluoro-2-butyltetrahydrofuran) were degassed and dried over $4 \AA$ molecular sieves (beads) under $\mathrm{N}_{2}$ atmospheres; $\mathrm{C}_{6} \mathrm{~F}_{6}$ was used as received; $\mathrm{CDCl}_{3}, \mathrm{CD}_{3} \mathrm{CN}, \mathrm{CD}_{2} \mathrm{Cl}_{2}$, acetone- $\mathrm{d}_{6}$, and $\mathrm{THF}-\mathrm{d}_{8}$ were dried over $4 \AA$ molecular sieves (beads) and used in a glove box. The thiols $\mathrm{HS}\left(\mathrm{CH}_{2}\right)_{n} \mathrm{R}_{\mathrm{f} 8} \quad(3, n=\mathbf{a}, 2 ; \mathbf{b}, 3)^{23}$ and clusters $\left[\mathrm{Ph}_{4} \mathrm{P}\right]_{2}\left[\mathrm{Fe}_{4} \mathrm{~S}_{4}\left(\mathrm{SC}\left(\mathrm{CH}_{3}\right)_{3}\right)_{4}\right](\mathbf{1})^{3}$ and $\left[\mathrm{Me}_{4} \mathrm{~N}\right]_{2}\left[\mathrm{Fe}_{4} \mathrm{~S}_{4}\left(\mathrm{SC}\left(\mathrm{CH}_{3}\right)_{3}\right)_{4}\right]$ $(2)^{3}$ were synthesized according to literature procedures. Other chemicals were used as received from common commercial sources; the $\mathrm{FeCl}_{3}$ and $\mathrm{CH}_{3} \mathrm{ONa}$ were stored and used in a glove box.

${ }^{1} \mathrm{H},{ }^{13} \mathrm{C}\left\{{ }^{1} \mathrm{H},{ }^{19} \mathrm{~F}\right\},{ }^{31} \mathrm{P}\left\{{ }^{1} \mathrm{H}\right\}$, and ${ }^{19} \mathrm{~F} \quad$ NMR spectra were recorded on 300 or $500 \mathrm{MHz}$ spectrometers in sealed tubes at ambient probe temperatures and referenced as follows $(\delta, \mathrm{ppm}):{ }^{1} \mathrm{H}$, residual internal $\mathrm{CHCl}_{3}(7.26), \mathrm{CHD}_{2} \mathrm{CN}$ (1.94), $\mathrm{CHDCl}_{2}$ (5.33), acetone- $\mathrm{d}_{5}$ (2.05), or $\mathrm{THF}_{-} \mathrm{d}_{7}(3.58,1.76) ;{ }^{13} \mathrm{C}$, internal $\mathrm{CDCl}_{3}$ (77.3), $\mathrm{CD}_{3} \mathrm{CN}$ (118.7), $\mathrm{CD}_{2} \mathrm{Cl}_{2}$ (54.0), acetone- $\mathrm{d}_{6}$ (29.9), or $\mathrm{THF}^{-\mathrm{d}_{8}}(25.4) ;{ }^{19} \mathrm{~F}$, external trifluoromethylbenzene $(-63.3) ;{ }^{31} \mathrm{P}$, external aqueous $85 \%$ phosphoric acid (0.0). UVvisible spectra were recorded using a Shimadzu UV spectrometer (UV-1800) with capped cuvettes. Microanalyses were conducted by Atlantic Microlab.

Crude $\left[\mathrm{Ph}_{3} \mathrm{P}\left(\mathrm{CH}_{2}\right)_{2} \mathbf{R}_{\mathrm{f6}}\right]_{2}\left[\mathrm{Fe}_{4} \mathrm{~S}_{4}\left(\mathrm{SC}\left(\mathrm{CH}_{3}\right)_{3}\right)_{4}\right]$ (8). In a procedure similar to those reported for $\mathbf{1}$ and $2,{ }^{3}$ a Schlenk flask was charged with $\mathrm{CH}_{3} \mathrm{ONa}(1.62 \mathrm{~g}, 30.0 \mathrm{mmol})$ and $\mathrm{CH}_{3} \mathrm{OH}$ $(30 \mathrm{~mL})$, and $\mathrm{HSC}\left(\mathrm{CH}_{3}\right)_{3}(3.4 \mathrm{~mL}, 30.2 \mathrm{mmol})$ was added by syringe with stirring. After $5 \mathrm{~min}$, a solution of anhydrous $\mathrm{FeCl}_{3}(1.21 \mathrm{~g}, 7.47 \mathrm{mmol})$ in $\mathrm{CH}_{3} \mathrm{OH}(20 \mathrm{~mL})$ was added. After $5 \mathrm{~min}$, sulfur $(0.240 \mathrm{~g}, 7.50 \mathrm{mmol})$ was added. After $16 \mathrm{~h}$, the mixture was filtered. A Schlenk flask was charged with $\left[\mathrm{Ph}_{3} \mathrm{P}\right.$ $\left.\left(\mathrm{CH}_{2}\right)_{2} \mathrm{R}_{\mathrm{f} 6}\right][\mathrm{I}]\left(7,{ }^{24} 4.18 \mathrm{~g}, 5.68 \mathrm{mmol}\right)$ and the filtrate with stirring. After $2 \mathrm{~h}$, the mixture was concentrated to dryness. The sticky solid was dissolved in THF $(20 \mathrm{~mL})$, and $\mathrm{Et}_{2} \mathrm{O}(120 \mathrm{~mL})$ was added. The mixture was stored at $-35^{\circ} \mathrm{C}$. After $24 \mathrm{~h}$, the sample was filtered. The black solid was extracted with $\mathrm{CH}_{3} \mathrm{CN}$, and the extracts were filtered. The solvent was removed by oil pump vacuum, and the sticky black solid was extracted with THF. The extract was filtered and the solvent was removed by oil pump vacuum. The black solid was washed with $\mathrm{Et}_{2} \mathrm{O}$ and dried by oil pump vacuum to give crude 8 $(0.921 \mathrm{~g}, 0.48 \mathrm{mmol}, 25 \%)$. Although the sample is impure by NMR, this does not affect preparative use.

$[\mathrm{Q}]_{2}\left[\mathrm{Fe}_{4} \mathbf{S}_{4}\left(\mathbf{S}\left(\mathrm{CH}_{2}\right)_{n} \mathbf{R}_{\mathrm{f8}}\right)_{4}\right]$ (general procedure). A Schlenk flask was charged with 1,2 , or $8(0.138 \mathrm{~g}, 0.086 \mathrm{~g}$, or $0.200 \mathrm{~g}$; $0.100 \mathrm{mmol})$ and $\mathrm{CH}_{3} \mathrm{CN}(10 \mathrm{~mL})$. Then $3 \mathrm{a}(0.300 \mathrm{~g}$, $0.625 \mathrm{mmol})$ or $3 \mathbf{b}(0.250 \mathrm{~g}, 0.506 \mathrm{mmol})$ was added with stirring. After $12 \mathrm{~h}$, the solvent was slowly removed by oil pump vacuum. The black solid was washed with $\mathrm{Et}_{2} \mathrm{O} /$ hexane $(33: 67$ $\mathrm{v} / \mathrm{v}$; samples are pure by NMR at this stage) and recrystallized from $\mathrm{CH}_{3} \mathrm{CN} / \mathrm{Et}_{2} \mathrm{O}$ or $\mathrm{THF} /$ hexane to give a dark brown solid
(4, $0.199 \mathrm{~g}, 0.067 \mathrm{mmol}, 67 \%$; 5, $0.201 \mathrm{~g}, 0.067 \mathrm{mmol}, 67 \%$; 6, $0.170 \mathrm{~g}, 0.069 \mathrm{mmol}, 69 \%$; 9, $0.256 \mathrm{~g}, 0.073 \mathrm{mmol}, 73 \%)$.

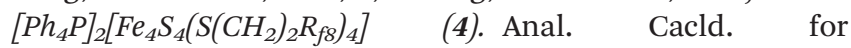
$\mathrm{C}_{88} \mathrm{H}_{56} \mathrm{~F}_{68} \mathrm{Fe}_{4} \mathrm{P}_{2} \mathrm{~S}_{8}$ : C, 35.86; H, 1.92; S, 8.70. Found: C, 35.16; $\mathrm{H}, 1.78 ; \mathrm{S}$, 8.36. MS $\left(\mathrm{m} / z\right.$, negative ESI): 1133.79, $\left[\mathrm{Fe}_{4} \mathrm{~S}_{4^{-}}\right.$ $\left.\left(\mathrm{S}\left(\mathrm{CH}_{2}\right)_{2} \mathrm{R}_{\mathrm{f} 8}\right)_{4}\right]^{2-}, 100 \%$ (calc. for $1132.8 / 1133.3 / 1133.8 / 1334.3 /$ 1134.8: $23: 13: 100: 58: 50$; found: $26: 13: 100: 27: 20)$.

$\operatorname{NMR}\left(\delta, \mathrm{CD}_{2} \mathrm{Cl}_{2}\right):{ }^{1} \mathrm{H}(300 \mathrm{MHz}) 11.6\left(\mathrm{br} \mathrm{s}, 8 \mathrm{H}, 4 \mathrm{SCH}_{2}\right), 7.83$ $\left(\mathrm{s}, 8 \mathrm{H}, 8 p-\mathrm{C}_{6} \underline{\mathrm{H}}_{5}\right), 7.68$ and 7.55 (s and d, $J_{\mathrm{HP}}=7.8 \mathrm{~Hz}, 2 \times 16 \mathrm{H}$, $\left.80, m-\mathrm{C}_{6} \underline{\mathrm{H}}_{5}\right), 2.29$ (br s, 8H, $\left.4 \mathrm{CH}_{2} \mathrm{R}_{\mathrm{f} 8}\right) ;{ }^{13} \mathrm{C}\left\{{ }^{1} \mathrm{H},{ }^{19} \mathrm{~F}\right\}(125 \mathrm{MHz})$ $136.3\left(\mathrm{~s}, \mathrm{C}_{\mathrm{Ar}}\right), 135.3\left(\mathrm{~d}, J_{\mathrm{CP}}=10.3 \mathrm{~Hz}, \mathrm{C}_{\mathrm{Ar}}\right), 131.5\left(\mathrm{~d}, J_{\mathrm{CP}}=13.0\right.$ $\left.\mathrm{Hz}, \mathrm{C}_{\mathrm{Ar}}\right), 123.9\left(\mathrm{~s}, \mathrm{C}_{\mathrm{F}}\right), 117.8\left(\mathrm{~d}, J_{\mathrm{CP}}=89.8 \mathrm{~Hz}, \mathrm{i}-\mathrm{C}_{\mathrm{Ar}}\right), 117.1(\mathrm{~s}$, $\left.\mathrm{C}_{\mathrm{F}}\right), 112.6\left(\mathrm{~s}, \mathrm{C}_{\mathrm{F}}\right), 111.5\left(\mathrm{~s}, \mathrm{C}_{\mathrm{F}}\right), 110.9\left(\mathrm{~s}, \mathrm{C}_{\mathrm{F}}\right), 110.8\left(\mathrm{~s}, \mathrm{C}_{\mathrm{F}}\right), 110.2$ $\left(\mathrm{s}, \mathrm{C}_{\mathrm{F}}\right), 108.4\left(\mathrm{~s}, \mathrm{C}_{\mathrm{F}}\right), 71.8\left(\mathrm{~s}, \mathrm{SCH}_{2}\right), 31.6\left(\mathrm{~s}, \mathrm{CH}_{2} \mathrm{R}_{\mathrm{f} 8}\right) ;{ }^{19} \mathrm{~F}$ $(282 \mathrm{MHz})-81.3\left(\mathrm{t}, J_{\mathrm{FF}}=10.1 \mathrm{~Hz}, 12 \mathrm{~F}, 4 \mathrm{CF}_{3}\right),-112.0(\mathrm{~s}, 8 \mathrm{~F}$, $\left.4 \mathrm{CF}_{2}\right),-121.7\left(\mathrm{~s}, 8 \mathrm{~F}, 4 \mathrm{CF}_{2}\right),-122.3\left(\mathrm{~m}, 16 \mathrm{~F}, 8 \mathrm{CF}_{2}\right),-122.6(\mathrm{~s}$, $\left.8 \mathrm{~F}, 4 \mathrm{CF}_{2}\right),-123.1\left(\mathrm{~s}, 8 \mathrm{~F}, 4 \mathrm{CF}_{2}\right),-126.5\left(\mathrm{~m}, 8 \mathrm{~F}, 4 \mathrm{CF}_{2}\right) ;{ }^{31} \mathrm{P}\left\{{ }^{1} \mathrm{H}\right\}$ $(202 \mathrm{MHz}) 25.2$ (s). UV-visible (nm, $6.11 \times 10^{-5} \mathrm{M}$ in $\mathrm{CH}_{3} \mathrm{CN}$ $\left.\left(\varepsilon, \mathrm{M}^{-1} \mathrm{~cm}^{-1}\right)\right): 294$ (22 200), 406 (16 000).

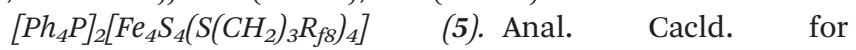
$\mathrm{C}_{92} \mathrm{H}_{64} \mathrm{~F}_{68} \mathrm{Fe}_{4} \mathrm{P}_{2} \mathrm{~S}_{8}$ : C, 36.79; H, 2.15; S, 8.54. Found: C, 35.62; $\mathrm{H}, 2.15 ; \mathrm{S}, 8.57 .^{35}$

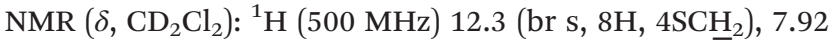
(s, $8 \mathrm{H}, 8 p-\mathrm{C}_{6} \underline{\mathrm{H}}_{5}$ ), 7.77 and 7.62 (s and d, $J_{\mathrm{HP}}=9.3 \mathrm{~Hz}, 2 \times 16 \mathrm{H}$, $\left.8 o, m-\mathrm{C}_{6} \underline{\mathrm{H}}_{5}\right), 2.71$ and 2.52 (2 br s, $2 \times 8 \mathrm{H}, 4 \mathrm{CH}_{2} \mathrm{C}_{2} \mathrm{R}_{\mathrm{f} 8}$ ); ${ }^{13} \mathrm{C}\left\{{ }^{1} \mathrm{H},{ }^{19} \mathrm{~F}\right\}(125 \mathrm{MHz}) 136.5\left(\mathrm{~s}, \mathrm{C}_{\mathrm{Ar}}\right), 135.4\left(\mathrm{~d}, J_{\mathrm{CP}}=10.3 \mathrm{~Hz}\right.$, $\left.\mathrm{C}_{\mathrm{Ar}}\right), 131.7\left(\mathrm{~d}, J_{\mathrm{CP}}=12.1 \mathrm{~Hz}, \mathrm{C}_{\mathrm{Ar}}\right), 120.6\left(\mathrm{~s}, \mathrm{C}_{\mathrm{F}}\right), 117.8\left(\mathrm{~d}, J_{\mathrm{CP}}=\right.$ $\left.89.3 \mathrm{~Hz}, \mathrm{i}-\mathrm{C}_{\mathrm{Ar}}\right), 117.1\left(\mathrm{~s}, \mathrm{C}_{\mathrm{F}}\right), 111.4\left(\mathrm{~s}, \mathrm{C}_{\mathrm{F}}\right), 111.3\left(\mathrm{~s}, \mathrm{C}_{\mathrm{F}}\right), 110.9$ $\left(\mathrm{s}, \mathrm{C}_{\mathrm{F}}\right), 110.8\left(\mathrm{~s}, \mathrm{C}_{\mathrm{F}}\right), 110.2\left(\mathrm{~s}, \mathrm{C}_{\mathrm{F}}\right), 108.4\left(\mathrm{~s}, \mathrm{C}_{\mathrm{F}}\right), 56.1\left(\mathrm{~s}, \mathrm{SCH}_{2}\right)$, 36.2 and $29.8\left(2 \mathrm{~s}, \mathrm{CH}_{2} \mathrm{CH}_{2} \mathrm{R}_{\mathrm{f} 8}\right) ;{ }^{19} \mathrm{~F}(470 \mathrm{MHz})-79.4\left(\mathrm{t}, J_{\mathrm{FF}}=\right.$ $\left.10.1 \mathrm{~Hz}, 12 \mathrm{~F}, 4 \mathrm{CF}_{3}\right),-110.8\left(\mathrm{~s}, 8 \mathrm{~F}, 4 \mathrm{CF}_{2}\right),-119.9\left(\mathrm{~s}, 8 \mathrm{~F}, 4 \mathrm{CF}_{2}\right)$, $-120.3\left(\mathrm{~s}, 16 \mathrm{~F}, 8 \mathrm{CF}_{2}\right),-121.1\left(\mathrm{~s}, 16 \mathrm{~F}, 8 \mathrm{CF}_{2}\right),-124.6(\mathrm{~m}, 8 \mathrm{~F}$,

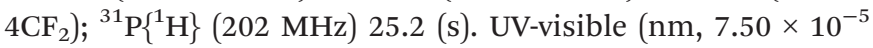
$\mathrm{M}$ in $\mathrm{CH}_{3} \mathrm{CN}\left(\varepsilon, \mathrm{M}^{-1} \mathrm{~cm}^{-1}\right)$ ): 297 (25 700), 410 (19 200).

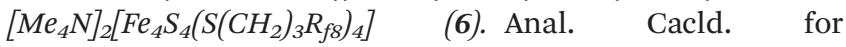
$\mathrm{C}_{52} \mathrm{H}_{48} \mathrm{~F}_{68} \mathrm{Fe}_{4} \mathrm{~N}_{2} \mathrm{~S}_{8}$ : C, 25.26; H, 1.96; N, 1.13; S, 10.37. Found: C, 23.71; H, 1.99; N, 1.30; S, 9.78. ${ }^{35}$

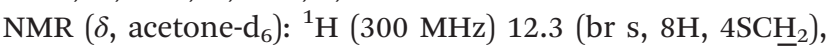
$3.45\left(\mathrm{~s}, 24 \mathrm{H}, 2\left(\mathrm{CH}_{3}\right)_{4} \mathrm{~N}\right), 2.85$ and $2.66(2$ br s, $2 \times \overline{8} \mathrm{H}$, $\left.4 \mathrm{CH}_{2} \mathrm{CH}_{2} \mathrm{R}_{\mathrm{f} 8}\right) ;{ }^{13} \mathrm{C}\left\{{ }^{\overline{1}} \mathrm{H},{ }^{19} \mathrm{~F}\right\}\left(\mathrm{CD}_{3} \mathrm{CN}, 125 \mathrm{MHz}\right) 120.7\left(\mathrm{~s}, \mathrm{C}_{\mathrm{F}}\right)$, $118.8\left(\mathrm{~s}, \mathrm{C}_{\mathrm{F}}\right), 111.5\left(\mathrm{~s}, \mathrm{C}_{\mathrm{F}}\right), 111.4\left(\mathrm{~s}, \mathrm{C}_{\mathrm{F}}\right), 110.9\left(\mathrm{~s}, \mathrm{C}_{\mathrm{F}}\right), 110.8(\mathrm{~s}$, $\left.\mathrm{C}_{\mathrm{F}}\right), 110.2\left(\mathrm{~s}, \mathrm{C}_{\mathrm{F}}\right), 108.4\left(\mathrm{~s}, \mathrm{C}_{\mathrm{F}}\right), 57.5$ and $55.8\left(2 \mathrm{~s}, \mathrm{SCH}_{2}\right.$ and $\left.\mathrm{CH}_{3}\right), 35.9$ and $29.0\left(2 \mathrm{~s}, \mathrm{CH}_{2} \mathrm{CH}_{2} \mathrm{R}_{\mathrm{f} 8}\right) ;{ }^{19} \mathrm{~F}(282 \mathrm{MHz})-81.7(\mathrm{t}$, $\left.J_{\mathrm{FF}}=10.3 \mathrm{~Hz}, 12 \mathrm{~F}, 4 \mathrm{CF}_{3}\right),-112.5\left(\mathrm{~m}, 8 \mathrm{~F}, 4 \mathrm{CF}_{2}\right),-121.9(\mathrm{~s}, 8 \mathrm{~F}$, $\left.4 \mathrm{CF}_{2}\right),-122.4\left(\mathrm{~s}, 16 \mathrm{~F}, 8 \mathrm{CF}_{2}\right),-123.0\left(\mathrm{~s}, 8 \mathrm{~F}, 4 \mathrm{CF}_{2}\right),-123.3(\mathrm{~s}, 8 \mathrm{~F}$, $\left.4 \mathrm{CF}_{2}\right),-126.8\left(\mathrm{~m}, 8 \mathrm{~F}, 4 \mathrm{CF}_{2}\right)$. UV-visible $\left(\mathrm{nm}, 8.09 \times 10^{-5} \mathrm{M}\right.$ in $\left.\mathrm{CH}_{3} \mathrm{CN}\left(\varepsilon, \mathrm{M}^{-1} \mathrm{~cm}^{-1}\right)\right): 298$ (30 800), 408 (22 500).

$\left[\mathrm{Ph}_{3} \mathrm{P}\left(\mathrm{CH}_{2}\right)_{2} \mathrm{R}_{\mathrm{f} 6}\right]_{2}\left[\mathrm{Fe}_{4} \mathrm{~S}_{4}\left(\mathrm{~S}\left(\mathrm{CH}_{2}\right)_{2} \mathrm{R}_{f 8}\right)_{4}\right]$ (9). Anal. Cacld. for $\mathrm{C}_{92} \mathrm{H}_{54} \mathrm{~F}_{94} \mathrm{Fe}_{4} \mathrm{P}_{2} \mathrm{~S}_{8}$ : C, 31.69; H, 1.56; S, 7.36. Found: C, 31.02; $\mathrm{H}, 1.55$; S, 7.08 .

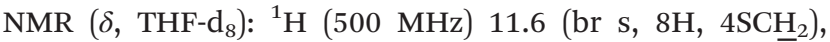
7.89-7.82 (m, 30H, 6C ${ }_{6} \underline{\mathrm{H}}_{5}$ ), 3.84 (br s, 4H, 2PC $\underline{\mathrm{H}}_{2}$ ), 2.70-2.48 $\left(\mathrm{m}, 12 \mathrm{H}, 2 \mathrm{CH}_{2} \mathrm{R}_{\mathrm{f} 6}\right.$ and $\left.4 \mathrm{CH}_{2} \mathrm{R}_{\mathrm{f} 8}\right) ;{ }^{13} \mathrm{C}\left\{{ }^{1} \mathrm{H},{ }^{19} \mathrm{~F}\right\}(125 \mathrm{MHz})^{36 a}$ $136.6\left(\mathrm{~s}, \mathrm{C}_{\mathrm{Ar}}\right), 136.2\left(\mathrm{~d}, J_{\mathrm{CP}}=10.2 \mathrm{~Hz}, \mathrm{C}_{\mathrm{Ar}}\right), 132.5\left(\mathrm{~d}, J_{\mathrm{CP}}=\right.$ 12.6 Hz, $\mathrm{C}_{\mathrm{Ar}}$ ), $124.0\left(\mathrm{~s}, \mathrm{C}_{\mathrm{F}}\right), 118.2\left(\mathrm{~s}, \mathrm{C}_{\mathrm{F}}\right), 118.1\left(\mathrm{~s}, \mathrm{C}_{\mathrm{F}}\right), 118.0(\mathrm{~d}$, $\left.J_{\mathrm{CP}}=87.0 \mathrm{~Hz}, \mathrm{i}-\mathrm{C}_{\mathrm{Ar}}\right), 117.5\left(\mathrm{~s}, \mathrm{C}_{\mathrm{F}}\right), 113.0\left(\mathrm{~s}, \mathrm{C}_{\mathrm{F}}\right), 112.0\left(\mathrm{~s}, \mathrm{C}_{\mathrm{F}}\right)$, 
$111.3\left(\mathrm{~s}, \mathrm{C}_{\mathrm{F}}\right), 111.2\left(\mathrm{~s}, \mathrm{C}_{\mathrm{F}}\right), 111.1\left(\mathrm{~s}, \mathrm{C}_{\mathrm{F}}\right), 110.6\left(\mathrm{~s}, \mathrm{C}_{\mathrm{F}}\right), 110.5(\mathrm{~s}$, $\left.\mathrm{C}_{\mathrm{F}}\right), 108.8\left(\mathrm{~s}, \mathrm{C}_{\mathrm{F}}\right), 73.0\left(\mathrm{~s}, \mathrm{SCH}_{2}\right), 31.3\left(\mathrm{~s}, \mathrm{CH}_{2}\right), 27.0\left(\mathrm{~s}, \mathrm{CH}_{2}\right)$, $19.9\left(\mathrm{~d}, J_{\mathrm{CP}}=56.7 \mathrm{~Hz}, \mathrm{CH}_{2}\right) ;{ }^{19} \mathrm{~F}(470 \mathrm{MHz})-81.9$ to $-82.0(\mathrm{~m}$, $\left.18 \mathrm{~F}, 6 \mathrm{CF}_{3}\right),-112.2\left(\mathrm{~s}, 8 \mathrm{~F}, 4 \mathrm{CF}_{2}\right),-112.6\left(\mathrm{~s}, 4 \mathrm{~F}, 2 \mathrm{CF}_{2}\right),-122.0(\mathrm{~s}$, $\left.8 \mathrm{~F}, 4 \mathrm{CF}_{2}\right),-122.4$ to $-122.7\left(\mathrm{~m}, 32 \mathrm{~F}, 16 \mathrm{CF}_{2}\right),-123.5(\mathrm{~s}, 12 \mathrm{~F}$, $\left.6 \mathrm{CF}_{2}\right),-127.0\left(\mathrm{~s}, 12 \mathrm{~F}, 6 \mathrm{CF}_{2}\right) ;{ }^{31} \mathrm{P}\left\{{ }^{1} \mathrm{H}\right\}(202 \mathrm{MHz}) 25.4$ (s). UV-visible (nm, $9.56 \times 10^{-5} \mathrm{M}$ in $\left.\mathrm{CH}_{3} \mathrm{CN}\left(\varepsilon, \mathrm{M}^{-1} \mathrm{~cm}^{-1}\right)\right): 295$ (26 300), 406 (17 900).

$[\mathrm{Na}]_{2}\left[\mathrm{Fe}_{4} \mathbf{S}_{\mathbf{4}}\left(\mathbf{S}\left(\mathrm{CH}_{2}\right)_{n} \mathbf{R}_{\mathrm{f8}}\right)_{4}\right]$. A (general procedure). A Schlenk flask was charged with $\mathrm{CH}_{3} \mathrm{ONa}(3.24 \mathrm{~g}, 60.0 \mathrm{mmol})$ and $\mathrm{CH}_{3} \mathrm{OH}(60 \mathrm{~mL})$, and $\mathrm{HSC}\left(\mathrm{CH}_{3}\right)_{3}(6.7 \mathrm{~mL}, 59.6 \mathrm{mmol})$ was added by syringe with stirring. After $5 \mathrm{~min}$, a solution of anhydrous $\mathrm{FeCl}_{3}(2.43 \mathrm{~g}, 15.0 \mathrm{mmol})$ in $\mathrm{CH}_{3} \mathrm{OH}(40 \mathrm{~mL})$ was added. After $5 \mathrm{~min}$, sulfur $(0.480 \mathrm{~g}, 15.0 \mathrm{mmol})$ was added. After $16 \mathrm{~h}$, the mixture was filtered. The solvent was removed from the filtrate by oil pump vacuum to give a black solid, which was washed with hexane/ $\mathrm{Et}_{2} \mathrm{O}(80: 20, \mathrm{v} / \mathrm{v})$ and dried by oil pump vacuum to give crude $[\mathrm{Na}]_{2}\left[\mathrm{Fe}_{4} \mathrm{~S}_{4}\left(\mathrm{SC}\left(\mathrm{CH}_{3}\right)_{3}\right)_{4}\right]$ (10; $3.21 \mathrm{~g}, \mathrm{ca} .4 .26 \mathrm{mmol})$. Another Schlenk flask was charged with 10 (0.380 g, ca. $0.504 \mathrm{mmol}$, or $0.190 \mathrm{~g}$, ca. $0.252 \mathrm{mmol})$ and $\mathrm{CH}_{3} \mathrm{CN}(50 \mathrm{~mL}$ or $25 \mathrm{~mL})$, and $3 \mathrm{a}(0.981 \mathrm{~g}, 2.04 \mathrm{mmol})$ or 3b $(0.494 \mathrm{~g}, 1.00 \mathrm{mmol})$ was added by syringe with stirring. The mixture was kept at $50{ }^{\circ} \mathrm{C}$ for $4 \mathrm{~h}$ and filtered. The filtrate was concentrated to dryness. The residue was washed with hexane and dried by oil pump vacuum to give crude $[\mathrm{Na}]_{2}\left[\mathrm{Fe}_{4} \mathrm{~S}_{4}\left(\mathrm{~S}\left(\mathrm{CH}_{2}\right)_{2} \mathrm{R}_{\mathrm{f8}}\right)_{4}\right](\mathbf{1 1} ; 0.816 \mathrm{~g}, 0.353 \mathrm{mmol}, 81 \%$ based

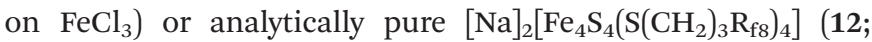
$0.254 \mathrm{~g}, 0.107 \mathrm{mmol}, 50 \%$ based on $\mathrm{FeCl}_{3}$ ) as black solids. $\mathbf{B}$. (alternative procedure for 11). A Schlenk flask was charged with $\mathrm{CH}_{3} \mathrm{ONa}(0.81 \mathrm{~g}, 15.0 \mathrm{mmol})$ and $\mathrm{CH}_{3} \mathrm{OH}(30 \mathrm{~mL})$, and $3 \mathrm{a}$ (7.20 g, $15.0 \mathrm{mmol}$ ) was added by syringe with stirring. After 5 min, a solution of anhydrous $\mathrm{FeCl}_{3}(0.61 \mathrm{~g}, 3.75 \mathrm{mmol})$ in $\mathrm{CH}_{3} \mathrm{OH}(15 \mathrm{~mL})$ was added. After $5 \mathrm{~min}$, sulfur $(0.120 \mathrm{~g}$, $3.75 \mathrm{mmol}$ ) was added. After $16 \mathrm{~h}$, the mixture was filtered. The solvent was removed from the filtrate by oil pump vacuum. The residue was washed with hexane/ $/ \mathrm{Et}_{2} \mathrm{O}(75: 25 \mathrm{v} / \mathrm{v})$ and dried by oil pump vacuum to give crude $\mathbf{1 1}$ as a black solid (1.65 g, $0.713 \mathrm{mmol}, 76 \%$ ). The ${ }^{19} \mathrm{~F}$ NMR spectra for both preparations of $\mathbf{1 1}$ showed impurities not evident in the ${ }^{1} \mathrm{H}$ NMR spectrum, but these are removed in subsequent cation metathesis steps.

$\left[\mathrm{Na}_{2}\left[\mathrm{Fe}_{4} \mathrm{~S}_{4}\left(\mathrm{~S}\left(\mathrm{CH}_{2}\right)_{3} \mathrm{R}_{f 8}\right)_{4}\right]\right.$ (12). Anal. Cacld. for $\mathrm{C}_{44} \mathrm{H}_{24} \mathrm{~F}_{68} \mathrm{Fe}_{4} \mathrm{Na}_{2} \mathrm{~S}_{8}$ : C, 22.29; H, 1.02; S, 10.82. Found: C, 21.92; $\mathrm{H}, 1.29 ; \mathrm{S}, 9.71$. $^{35}$

NMR $\left(\delta\right.$, THF-d $\left.\mathrm{d}_{8}\right):{ }^{1} \mathrm{H}(500 \mathrm{MHz}) 12.2\left(\mathrm{br} \mathrm{s}, 8 \mathrm{H}, 4 \mathrm{SCH}_{2}\right), 2.90$ and $2.66\left(2\right.$ br s, $\left.2 \times 8 \mathrm{H}, 4 \mathrm{CH}_{2} \mathrm{CH}_{2} \mathrm{R}_{\mathrm{f} 8}\right) ;{ }^{13} \mathrm{C}\left\{{ }^{1} \mathrm{H},{ }^{19} \mathrm{~F}\right\}(125 \mathrm{MHz})$ $122.5\left(\mathrm{~s}, \mathrm{C}_{\mathrm{F}}\right), 119.0\left(\mathrm{~s}, \mathrm{C}_{\mathrm{F}}\right), 113.4\left(\mathrm{~s}, \mathrm{C}_{\mathrm{F}}\right), 113.3\left(\mathrm{~s}, \mathrm{C}_{\mathrm{F}}\right), 112.8(\mathrm{~s}$, $\left.\mathrm{C}_{\mathrm{F}}\right), 112.7\left(\mathrm{~s}, \mathrm{C}_{\mathrm{F}}\right), 112.1\left(\mathrm{~s}, \mathrm{C}_{\mathrm{F}}\right), 110.3\left(\mathrm{~s}, \mathrm{C}_{\mathrm{F}}\right), 58.7\left(\mathrm{~s}, \mathrm{SCH}_{2}\right)$, 38.0 and $31.0\left(2 \mathrm{~s}, \mathrm{CH}_{2} \mathrm{CH}_{2} \mathrm{R}_{\mathrm{f} 8}\right) ;{ }^{19} \mathrm{~F}(470 \mathrm{MHz})-80.1(\mathrm{~s}, 12 \mathrm{~F}$, $\left.4 \mathrm{CF}_{3}\right),-111.0\left(\mathrm{~s}, 8 \mathrm{~F}, 4 \mathrm{CF}_{2}\right),-120.2\left(\mathrm{~s}, 8 \mathrm{~F}, 4 \mathrm{CF}_{2}\right),-120.7(\mathrm{~m}$, $\left.16 \mathrm{~F}, 8 \mathrm{CF}_{2}\right),-121.4\left(\mathrm{~s}, 8 \mathrm{~F}, 4 \mathrm{CF}_{2}\right),-121.5\left(\mathrm{~s}, 8 \mathrm{~F}, 4 \mathrm{CF}_{2}\right),-125.1(\mathrm{~s}$, $\left.8 \mathrm{~F}, 4 \mathrm{CF}_{2}\right)$.

$\left[\mathrm{PhCH}_{2} \mathrm{P}\left(\left(\mathrm{CH}_{2}\right)_{3} \mathrm{R}_{f 6}\right)_{3}\right][\mathrm{Br}]$ (13). A closed Schlenk flask was charged with $\mathrm{P}\left(\left(\mathrm{CH}_{2}\right)_{3} \mathrm{R}_{\mathrm{f} 6}\right)_{3}(0.277 \mathrm{~g}, 0.248 \mathrm{mmol}),{ }^{25}$ benzyl bromide $(0.051 \mathrm{~g}, 0.298 \mathrm{mmol})$, and toluene $(4 \mathrm{~mL})$. The mixture was kept at $100{ }^{\circ} \mathrm{C}$ for $2 \mathrm{~d}$ with stirring and cooled to room temperature. The upper layer was decanted. The lower layer was shaken with hexane and allowed to stand. The upper layer was decanted. Then $\mathrm{C}_{6} \mathrm{~F}_{6}$ was added to give a homogeneous solution. Then hexane was added ( $c a .10$ fold volumetric excess), and after $2 \mathrm{~d}$ the upper layer was decanted and the lower layer dried by oil pump vacuum to give 13 (0.205 g, $0.159 \mathrm{mmol}, 64 \%$ ) as a colorless sticky liquid. Anal. Cacld. for $\mathrm{C}_{34} \mathrm{H}_{25} \mathrm{BrF}_{39} \mathrm{P}: \mathrm{C}, 31.77 ; \mathrm{H}, 1.96$. Found: C, 31.56; H, 1.96.

$\operatorname{NMR}\left(\delta, \mathrm{CDCl}_{3}\right):{ }^{1} \mathrm{H}(500 \mathrm{MHz}) 7.42\left(\mathrm{~m}, 5 \mathrm{H}, \mathrm{C}_{6} \underline{\mathrm{H}}_{5}\right), 4.36(\mathrm{~d}$, $\left.J_{\mathrm{HP}}=14.9 \mathrm{~Hz}, 2 \mathrm{H}, \mathrm{PhCH}_{2} \mathrm{P}\right), 2.79\left(\mathrm{~m}, 6 \mathrm{H}, 3 \mathrm{PCH}_{2} \overline{\mathrm{CH}}_{2} \mathrm{CH}_{2} \mathrm{R}_{\mathrm{f} 6}\right)$, $2.29\left(\mathrm{~m}, \quad 6 \mathrm{H}, \quad 3 \mathrm{PCH}_{2} \mathrm{CH}_{2} \mathrm{CH}_{2} \mathrm{R}_{\mathrm{f}}\right), \quad 1.85 \quad(\mathrm{~m}, \quad 6 \mathrm{H}$, $\left.3 \mathrm{PCH}_{2} \mathrm{CH}_{2} \mathrm{CH}_{2} \mathrm{R}_{\mathrm{f} 6}\right) ;{ }^{13} \mathrm{C}\left\{{ }^{1} \mathrm{H},{ }^{19} \mathrm{~F}\right\}(125 \mathrm{MHz}) 130.1\left(\mathrm{~s}, \mathrm{C}_{\mathrm{Ar}}\right), 129.7$ $\left(\mathrm{d}, J_{\mathrm{CP}}=4.2 \mathrm{~Hz}, \mathrm{C}_{\mathrm{Ar}}\right), 129.4\left(\mathrm{~s}, \mathrm{C}_{\mathrm{Ar}}\right), 126.8\left(\mathrm{~d}, J_{\mathrm{CP}}=8.3 \mathrm{~Hz}, \mathrm{C}_{\mathrm{Ar}}\right)$, $117.8\left(\mathrm{~s}, \mathrm{C}_{\mathrm{F}}\right), 117.1\left(\mathrm{~s}, \mathrm{C}_{\mathrm{F}}\right), 110.9\left(\mathrm{~s}, \mathrm{C}_{\mathrm{F}}\right), 110.7\left(\mathrm{~s}, \mathrm{C}_{\mathrm{F}}\right), 110.1(\mathrm{~s}$, $\left.\mathrm{C}_{\mathrm{F}}\right), 108.4\left(\mathrm{~s}, \mathrm{C}_{\mathrm{F}}\right), 31.2\left(\mathrm{~d}, J_{\mathrm{CP}}=16.7 \mathrm{~Hz}, \mathrm{CH}_{2}\right), 26.9\left(\mathrm{~s}, \mathrm{CH}_{2}\right)$, $18.6\left(\mathrm{~d}, J_{\mathrm{CP}}=48.0 \mathrm{~Hz}, \mathrm{CH}_{2}\right), 13.7\left(\mathrm{~s}, \mathrm{CH}_{2}\right) ;{ }^{19} \mathrm{~F}(470 \mathrm{MHz})-80.9$ $\left(\mathrm{t}, J_{\mathrm{FF}}=9.5 \mathrm{~Hz}, 9 \mathrm{~F}, 3 \mathrm{CF}_{3}\right),-113.9\left(\mathrm{~m}, 6 \mathrm{~F}, 3 \mathrm{CF}_{2}\right),-121.9(\mathrm{~s}, 6 \mathrm{~F}$, $\left.3 \mathrm{CF}_{2}\right),-122.9\left(\mathrm{~s}, 6 \mathrm{~F}, 3 \mathrm{CF}_{2}\right),-123.4\left(\mathrm{~s}, 6 \mathrm{~F}, 3 \mathrm{CF}_{2}\right),-126.2(\mathrm{~m}, 6 \mathrm{~F}$, $\left.3 \mathrm{CF}_{2}\right) ;{ }^{31} \mathrm{P}\left\{{ }^{1} \mathrm{H}\right\}(202 \mathrm{MHz}) 28.9$ (s).

$\left[\mathrm{PhCH}_{2} \mathbf{P}\left(\left(\mathrm{CH}_{2}\right)_{3} \mathbf{R}_{\mathrm{f6}}\right)_{3}\right]_{2}\left[\mathrm{Fe}_{4} \mathrm{~S}_{4}\left(\mathbf{S}\left(\mathrm{CH}_{2}\right)_{n} \mathbf{R}_{\mathrm{f8}}\right)_{4}\right]$ (general procedure). A Schlenk flask was charged with $11(0.145 \mathrm{~g}$, $0.066 \mathrm{mmol})$ or $12(0.095 \mathrm{~g}, 0.040 \mathrm{mmol})$ and then $13(0.171 \mathrm{~g}$, $0.133 \mathrm{mmol}$ or $0.102 \mathrm{~g}, 0.079 \mathrm{mmol})$, and $\mathrm{CH}_{3} \mathrm{OH}(20 \mathrm{~mL})$ with stirring. After $0.5 \mathrm{~h}$, the supernatant was removed by syringe. The solid was extracted with THF. The extracts were concentrated to dryness and the crude product was crystallized from $\mathrm{THF} / \mathrm{hexane}(20: 80, \mathrm{v} / \mathrm{v})$ at $-35{ }^{\circ} \mathrm{C}$ and dried by oil pump vacuum to give $14(0.119 \mathrm{~g}, 0.025 \mathrm{mmol}, 39 \%)$ or $15(0.120 \mathrm{~g}$, $0.025 \mathrm{mmol}, 63 \%)$ as a dark brown solid.

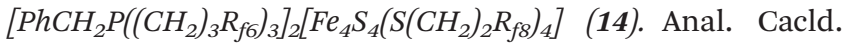
for $\mathrm{C}_{108} \mathrm{H}_{66} \mathrm{~F}_{146} \mathrm{Fe}_{4} \mathrm{P}_{2} \mathrm{~S}_{8}$ : C, 27.72; H, 1.42; S, 5.48. Found: C, 27.52; H, 1.48; S, 5.21.

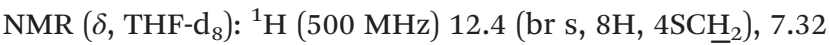
(br s, $10 \mathrm{H}, 2 \mathrm{C}_{6} \underline{\mathrm{H}}_{5}$ ), 3.75 (br s, $4 \mathrm{H}, 2 \mathrm{C}_{6} \mathrm{H}_{5} \mathrm{CH}_{2} \mathrm{P}$ ), 2.31 (m, 32H, $6 \mathrm{PCH}_{2} \mathrm{CH}_{2} \mathrm{CH}_{2} \mathrm{R}_{\mathrm{f} 6}, 6 \mathrm{PCH}_{2} \mathrm{CH}_{2} \mathrm{CH}_{2} \mathrm{R}_{\mathrm{f} 6}$ and $4 \mathrm{CH}_{2} \mathrm{R}_{\mathrm{f} 8}$ ), 1.93 (br s, $\left.12 \mathrm{H}, 6 \mathrm{PCH}_{2} \mathrm{CH}_{2} \mathrm{CH}_{2} \mathrm{R}_{\mathrm{f} 6}\right) ;{ }^{13} \mathrm{C}\left\{{ }^{1} \mathrm{H},{ }^{19} \mathrm{~F}\right\}(125 \mathrm{MHz}){ }^{36 b} 133.5$ (s, $\mathrm{C}_{\mathrm{Ar}}$ ), $131.6\left(\mathrm{~s}, \mathrm{C}_{\mathrm{Ar}}\right), 130.6\left(\mathrm{~s}, \mathrm{C}_{\mathrm{Ar}}\right), 129.9\left(\mathrm{~d}, J_{\mathrm{CP}}=4.2 \mathrm{~Hz}, \mathrm{C}_{\mathrm{Ar}}\right.$ ), $125.2\left(\mathrm{~s}, \mathrm{C}_{\mathrm{F}}\right), 120.7\left(\mathrm{~s}, \mathrm{C}_{\mathrm{F}}\right), 119.1\left(\mathrm{~s}, \mathrm{C}_{\mathrm{F}}\right), 119.0\left(\mathrm{~s}, \mathrm{C}_{\mathrm{F}}\right), 114.4(\mathrm{~s}$, $\left.\mathrm{C}_{\mathrm{F}}\right), 113.5\left(\mathrm{~s}, \mathrm{C}_{\mathrm{F}}\right), 113.0\left(\mathrm{~s}, \mathrm{C}_{\mathrm{F}}\right), 112.8\left(\mathrm{~s}, \mathrm{C}_{\mathrm{F}}\right), 112.7\left(\mathrm{~s}, \mathrm{C}_{\mathrm{F}}\right), 112.1$ $\left(\mathrm{s}, \mathrm{C}_{\mathrm{F}}\right), 110.4\left(\mathrm{~s}, \mathrm{C}_{\mathrm{F}}\right), 110.3\left(\mathrm{~s}, \mathrm{C}_{\mathrm{F}}\right), 73.7\left(\mathrm{~s}, \mathrm{SCH}_{2}\right), 37.4\left(\mathrm{~s}, \mathrm{CH}_{2}\right)$, $31.5\left(\mathrm{~s}, \mathrm{CH}_{2}\right), 31.1\left(\mathrm{~s}, \mathrm{CH}_{2}\right), 17.8\left(\mathrm{~s}, \mathrm{CH}_{2}\right) ;{ }^{19} \mathrm{~F}(470 \mathrm{MHz})-82.1$ $\left(\mathrm{s}, 30 \mathrm{~F}, 10 \mathrm{CF}_{3}\right),-112.3\left(\mathrm{~s}, 8 \mathrm{~F}, 4 \mathrm{CF}_{2}\right),-113.8\left(\mathrm{~s}, 12 \mathrm{~F}, 6 \mathrm{CF}_{2}\right)$, $-122.3\left(\mathrm{~s}, 20 \mathrm{~F}, 10 \mathrm{CF}_{2}\right),-122.7$ to $-122.8\left(\mathrm{~m}, 24 \mathrm{~F}, 12 \mathrm{CF}_{2}\right)$, $-123.2\left(\mathrm{~s}, 12 \mathrm{~F}, 6 \mathrm{CF}_{2}\right),-123.6\left(\mathrm{~s}, 20 \mathrm{~F}, 10 \mathrm{CF}_{2}\right),-127.0(\mathrm{~s}, 20 \mathrm{~F}$, $\left.{ }_{10 \mathrm{CF}_{2}}\right) ;{ }^{31} \mathrm{P}\left\{{ }^{1} \mathrm{H}\right\}(202 \mathrm{MHz}) 35.0$ (s). UV-visible (nm $\left(\varepsilon, \mathrm{M}^{-1}\right.$ $\left.\mathrm{cm}^{-1}\right)$ ): $5.56 \times 10^{-5} \mathrm{M}$ in THF, 292 (23 700), 410 (17 800); $7.78 \times$ $10^{-5} \mathrm{M}$ in FC-72, 415 (11 700).

$\left[\mathrm{PhCH}_{2} \mathrm{P}\left(\left(\mathrm{CH}_{2}\right)_{3} \mathrm{R}_{\mathrm{f}}\right)_{3}\right]_{2}\left[\mathrm{Fe}_{4} \mathrm{~S}_{4}\left(\mathrm{~S}\left(\mathrm{CH}_{2}\right)_{3} \mathrm{R}_{f 8}\right)_{4}\right]$ (15). Anal. Cacld. for $\mathrm{C}_{112} \mathrm{H}_{74} \mathrm{~F}_{146} \mathrm{Fe}_{4} \mathrm{P}_{2} \mathrm{~S}_{8}$ : C, 28.41; H, 1.58; S, 5.42. Found: C, 28.57; H, 1.56; S, 5.22.

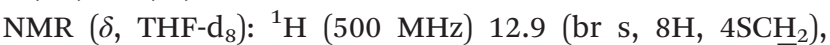
7.42-7.34 (m, $10 \mathrm{H}, 2 \mathrm{C}_{6} \underline{\mathrm{H}}_{5}$ ), 3.83 (br s, $\left.4 \mathrm{H}, 2 \mathrm{C}_{6} \mathrm{H}_{5} \mathrm{CH}_{2} \mathrm{P}\right), 2.90$ and $2.65\left(2\right.$ br s, $\left.2 \times 8 \mathrm{H}, 4 \mathrm{CH}_{2} \underline{\mathrm{CH}}_{2} \mathrm{R}_{\mathrm{f} 8}\right), 2.41(\mathrm{br} \mathrm{s}, 24 \mathrm{H}$, $6 \mathrm{PCH}_{2} \mathrm{CH}_{2} \mathrm{CH}_{2} \mathrm{R}_{\mathrm{f} 6}$ and $6 \mathrm{PCH}_{2} \mathrm{CH}_{2} \mathrm{CH}_{2} \mathrm{R}_{\mathrm{f} 6}$ ), 2.02 (br s, $12 \mathrm{H}$, $\left.6 \mathrm{PCH}_{2} \mathrm{CH}_{2} \mathrm{CH}_{2} \mathrm{R}_{\mathrm{f} 6}\right) ;{ }^{13} \mathrm{C}\left\{{ }^{1} \mathrm{H},{ }^{19} \mathrm{~F}\right\}(125 \mathrm{MHz}){ }^{36 c} 132.0\left(\mathrm{~s}, \mathrm{C}_{\mathrm{Ar}}\right)$, $129.7\left(\mathrm{~s}, \mathrm{C}_{\mathrm{Ar}}\right), 128.7\left(\mathrm{~s}, \mathrm{C}_{\mathrm{Ar}}\right), 128.0\left(\mathrm{~d}, J_{\mathrm{CP}}=8.1 \mathrm{~Hz}, \mathrm{C}_{\mathrm{Ar}}\right), 120.5$ 
$\left(\mathrm{s}, \mathrm{C}_{\mathrm{F}}\right), 118.9\left(\mathrm{~s}, \mathrm{C}_{\mathrm{F}}\right), 117.2\left(\mathrm{~s}, \mathrm{C}_{\mathrm{F}}\right), 117.1\left(\mathrm{~s}, \mathrm{C}_{\mathrm{F}}\right), 111.4\left(\mathrm{~s}, \mathrm{C}_{\mathrm{F}}\right)$, $111.4\left(\mathrm{~s}, \mathrm{C}_{\mathrm{F}}\right), 111.1\left(\mathrm{~s}, \mathrm{C}_{\mathrm{F}}\right), 110.9\left(\mathrm{~s}, \mathrm{C}_{\mathrm{F}}\right), 110.9\left(\mathrm{~s}, \mathrm{C}_{\mathrm{F}}\right), 110.8(\mathrm{~s}$, $\left.\mathrm{C}_{\mathrm{F}}\right), 110.3\left(\mathrm{~s}, \mathrm{C}_{\mathrm{F}}\right), 108.5\left(\mathrm{~s}, \mathrm{C}_{\mathrm{F}}\right), 108.4\left(\mathrm{~s}, \mathrm{C}_{\mathrm{F}}\right), 36.2\left(\mathrm{~s}, \mathrm{CH}_{2}\right), 35.7$ $\left(\mathrm{s}, \mathrm{CH}_{2}\right), 16.2\left(\mathrm{~s}, \mathrm{CH}_{2}\right) ;{ }^{19} \mathrm{~F}(470 \mathrm{MHz})-80.1$ to $-80.2(\mathrm{~m}, 30 \mathrm{~F}$, $\left.10 \mathrm{CF}_{3}\right),-111.3\left(\mathrm{~s}, 8 \mathrm{~F}, 4 \mathrm{CF}_{2}\right),-112.0\left(\mathrm{~s}, 12 \mathrm{~F}, 6 \mathrm{CF}_{2}\right),-120.4(\mathrm{~m}$, $\left.20 \mathrm{~F}, 10 \mathrm{CF}_{2}\right),-120.8\left(\mathrm{~s}, 20 \mathrm{~F}, 10 \mathrm{CF}_{2}\right),-121.3\left(\mathrm{~s}, 12 \mathrm{~F}, 6 \mathrm{CF}_{2}\right)$, $-121.7\left(\mathrm{~s}, \quad 24 \mathrm{~F}, \quad 12 \mathrm{CF}_{2}\right), \quad-125.1 \quad\left(\mathrm{~s}, 20 \mathrm{~F}, \quad 10 \mathrm{CF}_{2}\right) ;{ }^{31} \mathrm{P}\left\{{ }^{1} \mathrm{H}\right\}$ $(202 \mathrm{MHz}) 35.3$ (s). UV-visible (nm $\left.\left(\varepsilon, \mathrm{M}^{-1} \mathrm{~cm}^{-1}\right)\right): 7.18 \times 10^{-5}$ $\mathrm{M}$ in THF, 290 (27 800), 415 (21 900); $9.88 \times 10^{-5} \mathrm{M}$ in FC-72, 422 (16 900).

$[\mathrm{PPN}]_{2}\left[\mathrm{Fe}_{4} \mathrm{~S}_{4}\left(\mathrm{~S}\left(\mathrm{CH}_{2}\right)_{2} \mathrm{R}_{f 8}\right)_{4}\right]$ (16). A Schlenk flask was charged with $11(0.218 \mathrm{~g}, \quad 0.094 \mathrm{mmol}),[\mathrm{PPN}][\mathrm{Cl}]^{26}(\mathrm{PPN}=$ $\left.\mathrm{Ph}_{3} \mathrm{P} \cdots \mathrm{N} \cdots \mathrm{PPh}_{3} ; 0.120 \mathrm{~g}, 0.209 \mathrm{mmol}\right)$, and $\mathrm{CH}_{3} \mathrm{OH}(10 \mathrm{~mL})$ with stirring. After $2 \mathrm{~h}$, the mixture was cooled to $0^{\circ} \mathrm{C}$ and concentrated to $c a .1 \mathrm{~mL}$. A solid formed, and the supernatant was removed by syringe. The solid was extracted with THF $(8 \mathrm{~mL})$. The solvent was removed from the extract by oil pump vacuum. The solid was washed with $\mathrm{Et}_{2} \mathrm{O} /$ hexane $(17: 83, \mathrm{v} / \mathrm{v})$, crystallized from THF/hexane $(20: 80 \mathrm{v} / \mathrm{v})$ at $-35^{\circ} \mathrm{C}$, and dried by oil pump vacuum to give $16(0.112 \mathrm{~g}, 0.034 \mathrm{mmol}, 36 \%)$ as dark brown plates. Anal. Cacld. for $\mathrm{C}_{112} \mathrm{H}_{76} \mathrm{~F}_{68} \mathrm{Fe}_{4} \mathrm{~N}_{2} \mathrm{P}_{4} \mathrm{~S}_{8}$ : C, 40.21; H, 2.29; N, 0.84; S, 7.67. Found: C, 39.75; H, 2.27; N, $0.89 ; \mathrm{S}, 6.90 .^{35}$

NMR $\left(\delta\right.$, THF-d $\left.\mathrm{d}_{8}\right):{ }^{1} \mathrm{H}(500 \mathrm{MHz}) 11.4$ (br s, 8H, 4SCH$\left.\underline{\mathrm{S}}_{2}\right)$, 7.58-7.48 (m, 60H, 12 $\left.\mathrm{C}_{6} \underline{\mathrm{H}}_{5}\right), 2.46$ (br s, 8H, 4C $\left.\underline{\mathrm{H}}_{2} \overline{\mathrm{R}}_{\mathrm{f} 8}\right)$; ${ }^{13} \mathrm{C}\left\{{ }^{1} \mathrm{H},{ }^{19} \mathrm{~F}\right\}(125 \mathrm{MHz}) 136.6\left(\mathrm{~s}, \mathrm{C}_{\mathrm{Ar}}\right), 135.3\left(\mathrm{t}, J_{\mathrm{CP}}=4.6 \mathrm{~Hz}, \mathrm{C}_{\mathrm{Ar}}\right)$, $132.6\left(\mathrm{t}, J_{\mathrm{CP}}=5.6 \mathrm{~Hz}, \mathrm{C}_{\mathrm{Ar}}\right), 129.9\left(\mathrm{~d}, J_{\mathrm{CP}}=107.9 \mathrm{~Hz}, \mathrm{C}_{\mathrm{Ar}}\right), 125.7$ $\left(\mathrm{s}, \mathrm{C}_{\mathrm{F}}\right), 119.0\left(\mathrm{~s}, \mathrm{C}_{\mathrm{F}}\right), 114.6\left(\mathrm{~s}, \mathrm{C}_{\mathrm{F}}\right), 113.6\left(\mathrm{~s}, \mathrm{C}_{\mathrm{F}}\right), 112.9\left(\mathrm{~s}, \mathrm{C}_{\mathrm{F}}\right)$, 112.7 (s, $\left.\mathrm{C}_{\mathrm{F}}\right), 112.1$ (s, $\left.\mathrm{C}_{\mathrm{F}}\right), 110.3\left(\mathrm{~s}, \mathrm{C}_{\mathrm{F}}\right), 75.7\left(\mathrm{~s}, \mathrm{SCH}_{2}\right), 33.1$ (s, $\left.\mathrm{CH}_{2} \mathrm{R}_{\mathrm{f} 8}\right) ;{ }^{19} \mathrm{~F}(470 \mathrm{MHz})-80.0\left(\mathrm{t}, J_{\mathrm{FF}}=10.2 \mathrm{~Hz}, 12 \mathrm{~F}, 4 \mathrm{CF}_{3}\right)$, $-110.1\left(\mathrm{~s}, 8 \mathrm{~F}, 4 \mathrm{CF}_{2}\right),-120.0\left(\mathrm{~s}, 8 \mathrm{~F}, 4 \mathrm{CF}_{2}\right),-120.7(\mathrm{~s}, 24 \mathrm{~F}$, $\left.12 \mathrm{CF}_{2}\right),-121.6\left(\mathrm{~s}, 8 \mathrm{~F}, 4 \mathrm{CF}_{2}\right),-125.1\left(\mathrm{~m}, 8 \mathrm{~F}, 4 \mathrm{CF}_{2}\right) ;{ }^{31} \mathrm{P}\left\{{ }^{1} \mathrm{H}\right\}$ (202 MHz) 21.5 (s). UV-visible (nm, $9.97 \times 10^{-5} \mathrm{M}$ in $\mathrm{CH}_{3} \mathrm{CN}$ $\left.\left(\varepsilon, \mathrm{M}^{-1} \mathrm{~cm}^{-1}\right)\right): 406$ (10 900).

\section{Partition coefficients}

A. A volumetric flask $(25 \mathrm{~mL})$ was charged with 15 (0.0140 g, $0.00296 \mathrm{mmol})$ and $\mathrm{CF}_{3} \mathrm{C}_{6} \mathrm{~F}_{11}(25 \mathrm{~mL})$, capped, and vigorously shaken. Then $5.0 \mathrm{~mL}$ was transferred to a vial and toluene $(5.0 \mathrm{~mL})$ was added. The mixture was thoroughly shaken and allowed to stand. The two phases were separated and analyzed by UV-visible spectroscopy under an inert atmosphere. The A values associated with the $413 \mathrm{~nm}$ bands were 2.0731 $\left(\mathrm{CF}_{3} \mathrm{C}_{6} \mathrm{~F}_{11}\right)$ and 0.0073 (toluene, an upper bound). Given the biased ratio $(>99.65:<0.35)$, no correction for $\varepsilon$ values was applied. An analogous protocol with 14 gave the same limiting ratio (>99.65: <0.35). B. A volumetric flask $(25 \mathrm{~mL})$ was charged with $15(0.0117 \mathrm{~g}, 0.00247 \mathrm{mmol})$ and FC-72 $(25 \mathrm{~mL})$, capped, and vigorously shaken. Then $5.0 \mathrm{~mL}$ was transferred to a UVvisible cell, and the $420 \mathrm{~nm}$ band gave an A value of 1.6668. Another 5.0 mL aliquot was shaken with THF $(5.0 \mathrm{~mL})$. The sample was allowed to stand. The two phases were separated, and the fluorous phase exhibited a $420 \mathrm{~nm}$ band with an $\mathrm{A}$ value of 1.5523. This gave a FC-72/THF partition coefficient of 93.1 : 6.9. An analogous protocol with 14 gave a similar ratio $(93.2: 6.8)$.

\section{Cyclic voltammetry}

Electrochemical studies were preformed utilizing a Metrohm Eco Chemie Autolab PGSTAT30 potentiostat/galvanostat with a FRA2-module for electrochemical impedance studies and a bipotentiostat module. The General Purpose Electrochemical Software (GPES) supplied by the potentiostat manufacturer was utilized to record and process the data. All manipulations and studies were performed in a dry box under a nitrogen atmosphere. The DMF was dried using an Innovative Technology, Pure Solv solvent purifier with a double purifying column and thoroughly degassed by a nitrogen sparge prior to use. Experiments were performed using a three electrode cell fitted with a Pt working microelectrode $(10 \mu \mathrm{M}$ diameter, $\mathrm{CH}$ Instruments, Inc., CHI107), a Pt wire counter electrode, a Ag/Ag $\mathrm{NO}_{3}$ reference electrode $\left(\mathrm{Ag}\right.$ wire dipped in a $0.010 \mathrm{M} \mathrm{AgNO}_{3}$ solution prepared in a $0.10 \mathrm{M}\left[n-\mathrm{Bu}_{4} \mathrm{~N}\right]\left[\mathrm{PF}_{6}\right]$ solution in acetonitrile), a scan rate of $100 \mathrm{mV} \mathrm{s}^{-1}$, and DMF solutions that were $5.0 \times 10^{-4} \mathrm{M}$ in analyte and $3.0 \times 10^{-3} \mathrm{M}$ in $\left[n-\mathrm{Bu}_{4} \mathrm{~N}\right]\left[\mathrm{B}\left(\mathrm{C}_{6} \mathrm{~F}_{5}\right)_{4}\right]$ supporting electrolyte (synthesized by a literature procedure). ${ }^{37}$ Potentials were referenced to an external ferrocene/ferrocenium reference redox couple $\left(E^{\circ}=0.0919 \mathrm{~V}\right.$ vs. $\left.\mathrm{Ag} / \mathrm{AgNO}_{3}\right)$.

\section{Acknowledgements}

The authors thank the Qatar National Research Fund (project number 5-845-1-142; C.-P.Z., Z.X., H.S.B., J.A.G.), Welch Foundation (F-1631; K.M.M., B.J.H.), and US National Science Foundation (CHE-0847763; K.M.M., B.J.H.) for support, Dr Debaprasad Mandal for preliminary observations and a mass spectrum, and Prof. William E. Geiger (University of Vermont) for helpful discussions and recommendations on electrolytes.

\section{Notes and references}

1 Iron Sulfur Clusters in Chemistry and Biology, ed. T. Rouault, De Gruyter, Berlin, 2014.

2 (a) P. V. Rao and R. H. Holm, Chem. Rev., 2004, 104, 527559; (b) S. C. Lee, W. Lo and R. H. Holm, Chem. Rev., 2014, 114, 3579-3600.

3 (a) B. A. Averill, T. Herskovitz, R. H. Holm and J. A. Ibers, J. Am. Chem. Soc., 1973, 97, 3523-3532; (b) G. Christou and C. D. Garner, J. Chem. Soc., Dalton Trans., 1979, 1093-1094; (c) G. Christou, C. D. Garner, A. Balasubramaniam, B. Ridge and H. N. Rydo, Inorg. Synth., 1982, 33-37.

4 (a) L. Que Jr., M. A. Bobrik, J. A. Ibers and R. H. Holm, J. Am. Chem. Soc., 1974, 96, 4168-4178; (b) G. R. Dukes and R. H. Holm, J. Am. Chem. Soc., 1975, 97, 528-533; (c) R. C. Job and T. C. Bruice, Proc. Natl. Acad. Sci. U. S. A., 1975, 72, 2478-2482; (d) R. W. Johnson and R. H. Holm, J. Am. Chem. Soc., 1978, 100, 5338-5344; (e) J. A. Weigel and R. H. Holm, J. Am. Chem. Soc., 1991, 113, 4184-4191; (f) R. J. M. Klein Gebbink, S. I. Klink, M. C. Feiters and 
R. J. M. Nolte, Eur. J. Inorg. Chem., 2000, 2087-2099; (g) M. Ueda and T. Mochida, Inorg. Chim. Acta, 2003, 353, 306-309; (h) W. Lo, S. Huang, S.-L. Zheng and R. H. Holm, Inorg. Chem., 2011, 50, 11082-11090.

5 (a) A. K. Sharma, N. Kim, C. S. Cameron, M. Lyndon and C. B. Gorman, Inorg. Chem., 2010, 49, 5072-5078; (b) W. Lo, T. A. Scott, P. Zhang, C.-C. Ling and R. H. Holm, J. Inorg. Biochem., 2011, 105, 497-508.

6 (a) B. V. DePamphilis, B. A. Averill, T. Herskovitz, L. Que Jr. and R. H. Holm, J. Am. Chem. Soc., 1974, 96, 4159-4167; (b) J. Cambray, R. W. Lane, A. G. Wedd, R. W. Johnson and R. H. Holm, Inorg. Chem., 1977, 16, 2565-2571; (c) Y. Okuno, K. Uoto, O. Yonemitsu and T. Tomohiro, J. Chem. Soc., Chem. Commun., 1987, 1018-1020; (d) A. Lenormand, P. Iveson and J. Jordanov, Inorg. Chim. Acta, 1996, 251, 119-123; (e) C. Zhou, J. W. Raebiger, B. M. Segal and R. H. Holm, Inorg. Chim. Acta, 2000, 300-302, 892-902; $(f)$ E. P. L. van der Geer, Q. Li, G. van Koten, R. J. M. Klein Gebbink and B. Hessen, Inorg. Chim. Acta, 2008, 361, 1811-1818.

7 (a) R. W. Lane, A. G. Wedd, W. O. Gillum, E. J. Laskowski, R. H. Holm, R. B. Frankel and G. C. Papaefthymiou, J. Am. Chem. Soc., 1977, 99, 2350-2352; (b) C. L. Hill, J. Renaud, R. H. Holm and L. E. Mortenson, J. Am. Chem. Soc., 1977, 99, 2549-2557; (c) J. G. Reynolds, E. J. Laskowski and R. H. Holm, J. Am. Chem. Soc., 1978, 100, 5315-5322; (d) E. J. Laskowski, R. B. Frankel, W. O. Gillum, G. C. Papaefthymiou, J. Renaud, J. A. Ibers and R. H. Holm, J. Am. Chem. Soc., 1978, 100, 5322-5337; (e) J. G. Reynolds, C. L. Coyle and R. H. Holm, J. Am. Chem. Soc., 1980, 102, 4350-4355.

8 (a) E. E. van Tamelen, J. A. Gladysz and J. S. Miller, J. Am. Chem. Soc., 1973, 95, 1347-1348; (b) E. E. van Tamelen, J. A. Gladysz and C. R. Brûlet, J. Am. Chem. Soc., 1974, 96, 3020-3021; (c) K. D. Karlin, Science, 1993, 261, 701-708; (d) J. C. Fontecilla-Camps, P. Amara, C. Cavazza, Y. Nicolet and A. Volbeda, Nature, 2009, 460, 814-822.

9 (a) T. A. Scott and H.-C. Zhou, Angew. Chem., Int. Ed., 2004, 116, 5746-5749, (Angew. Chem., 2004, 43, 5628-5631); (b) T. A. Scott, C. P. Berlinguette, R. H. Holm and H.-C. Zhou, Proc. Natl. Acad. Sci. U. S. A., 2005, 102, 97419744.

10 L. Deng and R. H. Holm, J. Am. Chem. Soc., 2008, 130, 9878-9886.

11 E. Münck and E. L. Bominaar, Science, 2008, 321, 14521453.

12 Handbook of Fluorous Chemistry, ed. J. A. Gladysz, D. P. Curran and I. T. Horváth, Wiley/VCH, Weinheim, 2004.

13 (a) C. Emnet, K. M. Weber, J. A. Vidal, C. S. Consorti, A. M. Stuart and J. A. Gladysz, Adv. Synth. Catal., 2006, 348, 1625-1634; (b) C. S. Consorti, M. Jurisch and J. A. Gladysz, Org. Lett., 2007, 9, 2309-2312; (c) D. Mandal, M. Jurisch, C. S. Consorti and J. A. Gladysz, Chem. - Asian J., 2008, 3, 1772-1782; (d) D. Mandal and J. A. Gladysz, Tetrahedron,
2010, 66, 1070-1077, and literature from other groups cited therein.

14 S. K. Ghosh, A. S. Ojeda, J. Guerrero-Leal, N. Bhuvanesh and J. A. Gladysz, Inorg. Chem., 2013, 52, 9369-9378.

15 J. A. Gladysz and C. Emnet, Fluorous Solvents and Related Media, in Handbook of Fluorous Chemistry, ed. J. A. Gladysz, D. P. Curran and I. T. Horváth, Wiley/VCH, Weinheim, 2004, ch. 3.

16 J. A. Gladysz, C. Emnet and J. Rábai, Partition Coefficients involving Fluorous Solvents, in Handbook of Fluorous Chemistry, ed. J. A. Gladysz, D. P. Curran and I. T. Horváth, Wiley/VCH, Weinheim, 2004, ch. 6.

17 (a) J. K. Nelson and I. F. M. Hashad, J. Phys. D: Appl. Phys., 1976, 9, 203-210; (b) H. K. Christenson and P. M. Claesson, Science, 1988, 239, 390-392.

18 (a) B. Remy, G. Deby-Dupont and M. Lamy, Br. Med. Bull., 1999, 55, 277-298; (b) D. R. Spahn, Critical Care, 1999, 3, R93-R97.

19 (a) J. R. Postgate, Nitrogen Fixation, Cambridge, UK, 3rd edn, 1998; (b) K. C. MacLeod and P. L. Holland, Nat. Chem., 2013, 5, 559-565.

20 (a) IUPAC Solubility Data Series, ed. R. Battino, Pergamon, New York, 1981, vol. 7, pp. 320 and 321; (b) IUPAC Solubility Data Series, ed. C. L. Young, Pergamon, New York, 1981, vol. 5/6, p. 243; (c) C. R. Patrick, Preparation, Properties, and Industrial Applications of Organofluorine Compounds, ed. R. E. Banks, Ellis Horwood, New York, 1982, p. 53.

21 R. Battino, T. R. Rettich and T. Tominaga, J. Phys. Chem. Ref. Data., 1984, 13, 563-600.

22 I. T. Horváth, D. P. Curran and J. A. Gladysz, Fluorous Chemistry: Scope and Definition, in Handbook of Fluorous Chemistry, ed. J. A. Gladysz, D. P. Curran and I. T. Horváth, Wiley/VCH, Weinheim, 2004, ch. 1.

23 (a) F. Szonyi and A. Cambon, J. Fluorine Chem., 1989, 42, 59-68; (b) C. Naud, P. Calas, A. Blancou and A. Commeyras, J. Fluorine Chem., 2000, 104, 173-183; (c) C. Rocaboy and J. A. Gladysz, New J. Chem., 2003, 27, 39-49.

24 C. Rocaboy, D. Rutherford, B. L. Bennett and J. A. Gladysz, J. Phys. Org. Chem., 2000, 13, 596-603.

25 (a) L. J. Alvey, D. Rutherford, J. J. J. Juliette and J. A. Gladysz, J. Org. Chem., 1998, 63, 6302-6308; (b) G. Vlád, F. Richter and I. Horváth, Org. Lett., 2004, 6, 4559-4561; (c) The exact route employed to this compound can be found in M. Jurish, doctoral dissertation, University Erlangen-Nürnberg, 2008. See also: C. Emnet and J. A. Gladysz, Synthesis, 2005, 1012-1018.

26 V. Y. Kukushkin and A. I. Moiseev, Inorg. Chim. Acta, 1990, 176, 79-81.

27 (a) W. R. Dolbier, Guide to Fluorine NMR for Organic Chemists, Wiley, Hoboken, New Jersey, 2009, p. 196; (b) J. A. Gladysz and M. Jurisch, Top. Curr. Chem., 2012, 308, 1-24.

28 M. Crozet, M. Chaussade, M. Bardet, L. Emsley, B. Lamotte and J.-M. Mouesca, J. Phys. Chem. A, 2000, 104, 999010000. 
29 H. Jiao, S. Le Stang, T. Soós, R. Meier, K. Kowski, P. Rademacher, L. Jafarpour, J.-B. Hamard, S. P. Nolan and J. A. Gladysz, J. Am. Chem. Soc., 2002, 124, 1516-1523.

30 C. Goh, B. M. Segal, J. Huang, J. R. Long and R. H. Holm, J. Am. Chem. Soc., 1996, 118, 11844-11853.

31 Microelectrodes: Theory and Applications, ed. I. Montenegro, M. A. Queirós and J. L. Daschbach, Springer, 1991.

32 A reviewer has noted that the shape of the $\mathrm{CV}$ traces in Fig. 1 (sigmoidal) differs from those often depicted in the literature (with cathodic and anodic peaks). This is a simple consequence of using microelectrodes as opposed to conventional electrodes; it is connected to edge effects (radial diffusion) that dominate over linear diffusion with very small electrodes: A. M. Bond, Analyst, 1994, 110, R1-R21.
33 (a) J. F. Harris Jr. and W. A. Sheppard, J. Org. Chem., 1961, 26, 354-358; (b) R. Freter, E. R. Pohl, J. M. Wilson and D. J. Hupe, J. Org. Chem., 1979, 44, 1771-1774; (c) D. J. Hupe and E. R. Pohl, Isr. J. Chem., 1985, 26, 395-399.

34 N. Privitera, R. Naon and J. G. Riess, Int. J. Pharm., 1994, 104, 41-48.

35 These data do not indicate an analytical pure sample, but are provided nonetheless to illustrate the best fit obtained to date.

36 Several carbon signals were not observed: (a) two $\mathrm{CF}_{2}$ signals; (b) one $\mathrm{CH}_{2}$ and two $\mathrm{CF}_{2}$ signals; (c) four $\mathrm{CH}_{2}$ and one $\mathrm{CF}_{2}$ signals.

37 D. Türp, J. Wagner, V. Enkelmann and K. Müllen, Angew. Chem., Int. Ed., 2011, 50, 4962-4965, (Angew. Chem., 2011, 123, 5064-5067). 